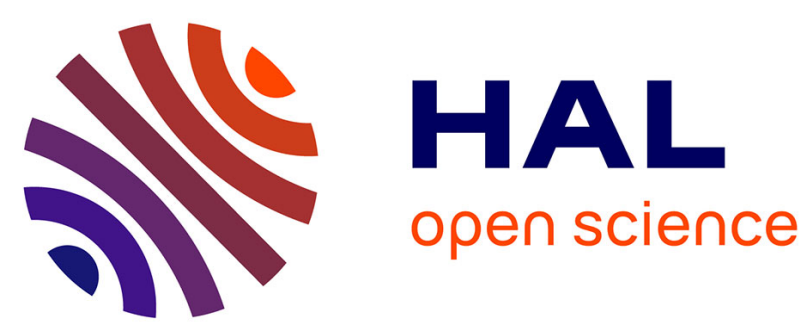

\title{
3D stratigraphic architecture, sedimentary budget, and sources of the Lower and Middle Triassic strata of western Canada: evidence for a major basin structural reorganization
}

Vincent Crombez, Sébastien Rohais, François Baudin, Tristan Euzen, John-Paul Zonneveld, Matthew Power

\section{To cite this version:}

Vincent Crombez, Sébastien Rohais, François Baudin, Tristan Euzen, John-Paul Zonneveld, et al.. 3D stratigraphic architecture, sedimentary budget, and sources of the Lower and Middle Triassic strata of western Canada: evidence for a major basin structural reorganization. Petroleum Geoscience, 2020, 26 (3), pp.462-479. 10.1144/petgeo2019-024 . hal-02430006

\section{HAL Id: hal-02430006 https://hal.science/hal-02430006}

Submitted on 17 Sep 2020

HAL is a multi-disciplinary open access archive for the deposit and dissemination of scientific research documents, whether they are published or not. The documents may come from teaching and research institutions in France or abroad, or from public or private research centers.
L'archive ouverte pluridisciplinaire HAL, est destinée au dépôt et à la diffusion de documents scientifiques de niveau recherche, publiés ou non, émanant des établissements d'enseignement et de recherche français ou étrangers, des laboratoires publics ou privés. 


\section{the Lower and Middle Triassic strata of Western Canada: evidence} for a major basin structural reorganization ZONNEVELD John-Paul ${ }^{4}$, POWER Matthew ${ }^{5}$

1 - IFP Énergies nouvelles, 1 et 4 Avenue de Bois-Préau, 92852 Rueil-Malmaison, France.

2 - Sorbonne Université, CNRS, ISTeP, 4 place Jussieu, 75005 Paris, France.

3 - IFP Technologies (Canada) Inc., Suite 810, 744 - 4th Avenue S.W., Calgary, AB, Canada.

4 - University of Alberta, 116 St and 85 Ave, Edmonton, AB, Canada.

5 - SGS Canada Inc., 3260 Production Way, Burnaby, BC, Canada.

\# - presently at CSIRO Deep Earth Imaging Future Science Platform, ARRC, 26 Dick Perry Avenue,

*_Corresponding author, (crombez.v@gmail.com) 
This study focuses on the Lower-Middle Triassic Montney, Sunset Prairie, Doig, and, Halfway formations from the foreland basin of the Canadian Cordillera (Alberta and British Columbia). Based on core and outcrop descriptions, correlation of 400 wells, and, on mineralogical analyses, this study interprets the basin-scale, 3D-stratigraphic architecture of these formations and discusses the controls on its evolution.

Well correlation highlights four sequences (1-4) interpreted to occur in two second-order cycles (A and B). In this work, the Lower Triassic Montney Formation and the early Middle Triassic Sunset Prairie Formation are interpreted to consist of three third-order sequences (1-3) related to the first second-order cycle (cycle A). The Middle Triassic Doig and Halfway formations are interpreted to consist of a fourth sequence (4) related to a second-order cycle (cycle B). Integration of stratigraphic surfaces with previously published biostratigraphic analyses emphasizes a major time gap of ca. $2 \mathrm{Ma}$ between these two cycles interpreted to record a major reorganization of the basin. Mineralogical analyses suggest that during cycle A, sediments were delivered from the east (Canadian Shield) whereas in cycle B additional sources from the west (proto Canadian Cordillera) occurred. This study shows the stratigraphic architecture evolution was affected by the structural heritage of the basin and continental geodynamic evolution. This study provides a large-scale understanding on the controls of the stratigraphic architecture of Lower and Middle Triassic strata suggesting local and regional controls on the reservoir extension and unconventional plays configuration within these strata. 
The geodynamic evolution of the Western Canada Sedimentary Basin (WCSB) was previously divided into two stages: (1) a passive margin prior to the Jurassic and (2) a foreland basin from the midJurassic to the present day (Price, 1994; Monger and Price, 2002). Nonetheless, recent studies on the Triassic strata from the WCSB (Golding et al., 2015 a; Onoué et al., 2016) and on the regional geodynamic evolution of Western Canada (Beranek and Mortensen, 2011; Rohais et al., 2018) present a more complex geodynamic and paleogeographic context during that time interval. However, these previous works did not integrate a detailed 3D stratigraphic architecture of the Lower and Middle Triassic strata into their analysis of the basin evolution.

In the past decade, the development of multi-disciplinary source-to-sink studies guided the analysis of sedimentary basins toward an integrated discipline. This type of study greatly helps in understanding (1) the local and regional evolution of basin sediment sources, and, (2) the structural and geodynamical evolution of the area based on the reading of the sedimentary records. It implies (1) the restoration of sedimentary basin architectures based on sequence stratigraphy to establish sedimentary budgets related to paleogeographic evolution (e.g. Rouby et al., 2009; Guillocheau et al., 2012; Rohais et al., 2016), (2) the determination of sources of sediments through provenance studies (Golding et al., 2015 a, 2016), (3) the restoration of catchments areas and characterization of the eroded material (Grimaud et al., 2018), and, (4) the integration of basin deformation and mechanisms driving subsidence (Contreras et al., 2010; Matenco et al., 2013; Guillocheau et al., 2015). Major advances in the dynamics of sedimentary basins have been proposed in recent years, for example on the Scandinavian (Martinsen et al., 2010), Mediterranean (Leroux et al., 2017) and Atlantic (Baby et al., 2018) margins.

The present work focuses on the Triassic Montney and Doig formations within the WCSB, following a source-to-sink approach. With its huge shale-oil and shale-gas potential and the development of new petroleum prospects in this interval, a new wealth of well data is available. This enables us to present a novel stratigraphic architecture for this interval and discuss the controls on the stratigraphic evolution of an organic-rich interval at basin scale and investigate its controls. This will result in a 
better estimation of the extent and geometric configuration of reservoirs within shale-plays in Western Canadian Lower and Middle Triassic successions.

The workflow developed here is divided in three main steps: (1) a study of the 3D stratigraphic architecture of the Lower and Middle Triassic strata based on well-log correlations calibrated with data from core and outcrop data following the concepts developed by Posamentier and Walker (2006) for facies and paleoenvironmental characterisation, and, Catuneanu (2006) for stratigraphic correlations, (2) the integration of this stratigraphic architecture in an existing temporal framework based on previous biostratigraphic studies (Orchard and Zonneveld, 2009; Golding et al., 2015 b; Henderson and Schoepfer, 2017), (3) an analysis of the relationship between the main sequence boundaries and the regional context, and, (4) the study of the sediment mineralogy variation across the interval and its implication on the sediment provenance. This analysis provides insight into the regional and local controls of geodynamics on the paleogeographic evolution and stratigraphic architecture of the Montney, Sunset Prairie, Doig and Halfway formations in the WCSB.

\section{LOWER AND MIDDLE TRIASSIC STRATA: WESTERN CANADA SEDIMENTARY BASIN}

In Western Canada, Triassic strata are present in two basins: (1) the Western Canada Sedimentary Basin (WCSB, Fig. 1) and (2) the Williston Basin (North Dakota and South Saskatchewan, Edwards et al., 1994). In the Williston basin, the Triassic interval consists of poorly-dated, continental red bed deposits (Cumming, 1956; Carlson, 1968; Edwards et al., 1994, Butcher et al., 2012) whereas in the WCSB, the Lower to Middle Triassic strata preserves a variety of marine and marginal marine environments (Armitage, 1962, Davies, 1997; Davies et al., 1997; Zonneveld et al., 1997; Dixon, 2000; Zonneveld et al., 2001; Zonneveld, 2001; Orchard and Zonneveld, 2009, Furlong et al., 2018 a). In the subsurface of the WCSB marine deposits of the Lower and Middle Triassic (approx. $15 \mathrm{Ma}$ of deposition, Orchard and Tozer, 1997) are divided into four formations from older to younger: the Montney, Sunset Prairie, Doig and, Halfway formations. 
In the WCSB (Fig. 1), Lower and Middle Triassic strata occur stratigraphically between the Permian Belloy Formation and the Upper Triassic Charlie Lake Formation or the regional sub-Jurassic erosional unconformity. The study interval consists primarily of fine-grained sandstone, siltstone, and shale with locally-occurring, sandy, bioclastic packstone and grainstone beds (Armitage, 1962; Gibson, 1974; Gibson, 1975; Davies, 1997; Davies et al., 1997; Zonneveld et al., 1997, 2001, 2010 a, 2010 b; Zonneveld, 2001; Crombez et al., 2016). Studies on the sedimentology and depositional environments of this interval highlight a wave-dominated environment, including phosphatic shale layers (Armitage, 1962, Gibson, 1974; Gibson, 1975; Evoy and Moslow, 1995; Davies et al., 1997; Evoy, 1995, 1997; Zonneveld et al., 1997; 2001; 2010 a, Zonneveld, 2001; Golding et al., 2014; Crombez et al., 2016; Euzen et al., 2018), turbiditic deposits (Moslow and Davies, 1997; Crombez et al., 2016) and evaporitic environments for the top of the Middle Triassic deposits (Davies, 1997; Zonneveld et al., 1997, 2001; Zonneveld, 2000). Various biostratigraphic studies (Orchard and Tozer, 1997; Zonneveld et al., 1997; Orchard and Zonneveld, 2009; Golding et al., 2015 b; Henderson and Schoepfer, 2017; Henderson et al., 2018) show that the Montney Formation was deposited during the Latest Permian and Early Triassic and the Doig and Halfway formations were deposited during the Middle to Late Triassic. The geodynamic setting during deposition of Lower and Middle Triassic strata is still a matter of debate: according to Davies et al. (1997), the Montney and Doig formations were deposited on the western passive margin of the Pangaea supercontinent, whereas Ferri and Zonneveld (2008) and Golding et al. (2015 a) suggested that these formations were deposited in an early foreland basin based on sediment provenance analyses. More recently, subsidence backstripping has corroborated the early foreland setting hypothesis (Rohais et al., 2018).

In the past, numerous studies have focused on the sub-regional stratigraphic architecture of the Montney (e.g. Markhasin, 1997; Kendall, 1999; Panek, 2000) or Doig formations (Evoy, 1995, 1997; Harris, 2000, Golding et al., 2015 b). More regional and older studies provided a stratigraphic framework for the Montney and Doig formations (Gibson and Barclay, 1989; Embry and Gibson, 1995; Embry, 1997; Davies et al., 1997), but did not benefit from the wealth of new data made 
available by the recent development of the distal unconventional part of the Montney-Doig play.

118 These studies highlight two second-order cycles: one in the Montney Formation; another one in the Doig and Halfway formations; and several third-order sequences within each second-order cycle.

The geometry and the extent of those sequences is one of the main controls on hydrocarbon reservoirs localization in these formations. Redefining a basin-scale stratigraphic architecture (sensu Catuneanu, 2006) based on the new wealth of well data available and understanding its link with the continent evolution is paramount for hydrocarbons exploration.

\section{DATA AND METHODS}

Data

The present work is based on data from over 2000 wells, provided by operators to the Alberta Energy Regulator and the British Columbia Oil and Gas Commission and uploaded through data providers including GeowebWorks, IHS Data Manager and Divestco Energisite. Well logs were collected and gathered in a PETREL database. This dataset is completed by 22 sedimentological sections from 18 cores and 4 outcrops and cuttings samples through the entire study interval from three wells (Fig. 1). From this database, 400 wells were selected along 18 regional cross-sections to reconstruct the stratigraphic architecture of the Lower and Middle Triassic (Fig. 1).

\section{Methods}

\section{Sedimentology and sequence stratigraphy}

135 Sedimentary facies were identified in core and depositional environments were interpreted. 136 Correlation of core descriptions with available well logs allowed interpretations to be upscaled through the interval of interest facilitating regional sequence stratigraphic correlations (following methods presented in Crombez et al. (2016). This interpretation was complemented by description and analysis of outcrop sections of Middle Triassic strata (Fig. 1). The analysis of the stacking pattern and spatial distribution of depositional environments makes it possible to define shoreline 
trajectories (Helland-Hansen and Martinsen, 1996; Helland-Hansen and Hampson, 2009) and to identify major stratigraphic surfaces: end of regression, end of transgression, onset of base level fall and end of base level fall (Catuneanu, 2006, Catuneanu et al., 2009). Following the terminology proposed by Hunt and Tucker (1992) and Helland-Hansen and Gjelberg (1994), these stratigraphic surfaces were used to reconstruct the 3D stratigraphic architecture of the studied interval. In the present work, the authors aim at providing regional correlation lines across the basin, that can serve as foundations for future works regardless of stratigraphic schools of thoughts. However, the names of the stratigraphic surfaces and the stratigraphic systems tracts refer to a new and local stratigraphic architecture for the Lower and Middle Triassic strata of the WCSB defined by the authors based on Catuneanu et al. (2009) perspective on stratigraphy admitting a cyclicity in sedimentary records.

\section{Mineralogical analyses}

QEMSCAN analyses (Gottlieb et al., 2000) were performed by SGS Canada Inc. on 201 cuttings samples. QEMSCAN is based on backscattered-electron imaging and energy dispersive X-ray spectroscopy techniques. It identifies individual minerals using a low-count energy-dispersive x-ray database. This system provides a quantification of individual minerals together with an image of their distribution in the samples.

\section{RESULTS}

\section{Sedimentary environments and depositional model}

Detailed descriptions of the sedimentary facies were presented in previous papers (Crombez et al., 2016; Euzen et al., 2018). In the present study, two additional environments were highlighted: (1) estuarine deposits, and (2) sabkha deposits. Figure 2 illustrates the different depositional environments with representative core photos and gamma log profiles. In the Lower and Middle Triassic, seven main sedimentary environments are recognized: (1) sabkha environment (Fig. 2 a), (2) estuarine and tidal environment (Fig. 2 b), (3) foreshore environment (Fig. 2 c), (4) shoreface 
environment (Fig. $\mathbf{2} \mathbf{d}$ and e), (5) turbiditic environment (Fig. $\mathbf{2}$ f), (6) offshore transition environment

(Fig. $\mathbf{2 ~ g}$ ), and, (7) offshore environment (Fig. $\mathbf{2}$ h). The marine depositional environments presented above are characteristic of a wave-dominated shelf (Suter, 2006). In our work, no clear evidence of deltaic environments was highlighted but previous studies identified these environments below the sub-Jurassic unconformity along the erosional edge, especially in the north-eastern part of the basin (e.g. Zonneveld et al., 2010 a, 2010 b; Zonneveld and Moslow, 2018).

Figure 2 illustrates the typical gamma ray profiles of the main environments encountered in this study. The figure shows that tidal deposits present a blocky pattern that is interpreted to represent the sharp transition between heterolithic tidal flat successions with sandy tidal channel units. Shoreface and foreshore deposits present the same coarsening upward trend but with depressed gamma ray profiles interpreted to be linked to the higher sand content. Turbiditic deposits are characterized by a major drop in the gamma radiation interpreted to represent a sharp depositional contact of sandstone above more highly radioactive offshore units. Unlike shoreface and foreshore environments, turbiditic deposits often present fining upward trends, interpreted to represent the lateral migration and/or waning of the turbiditic system. Turbiditic deposits also typically show high amplitude GR variations associated with high frequency changes in depositional energy and, concomitantly, lithology. Lastly, offshore and offshore transition successions present high gamma ray profiles with coarsening upward trends. The recognition of these distinctive patterns provides a means with which to interpret depositional environments and therefore vertical changes in relative depositional bathymetry on well logs (Crombez et al., 2016). However, it is important to note that as the facies recognition is mainly based on well-log pattern some intervals might be misinterpreted, however we are confident on the regional trends highlighted. Here, the absolute value of the gamma ray readings may vary depending on the tools used and the vintage of the data.

\section{Stratigraphic architecture along the 2D well sections}

\section{Regional stratigraphic sections}


The synthetic stratigraphic architecture of the Montney, Sunset Prairie, Doig, and Halfway formations

192 is presented in figure 3. On this figure, four sequence boundaries (named after the sequence they

193 form part of) are presented. They delimit four stratigraphic sequences: the first three sequences (sequences 1 -3) within the Montney Formation and the last sequence (sequence 4), within the Doig and Halfway formations. The sequences 1-3 are interpreted to be part of the older second-order cycle (cycle A) described in previous studies (Gibson and Barclay, 1989; Edwards et al., 1994; Davies, 1997) and sequence 4 is interpreted to be part of the younger, second-order cycle (cycle B) discussed in the same papers.

Three of the eighteen cross sections realized for the present study are presented in this paper (Figs. 1; 4-6). Figure 4 presents a 375 km long SE-NW section with 25 wells, figure 5 presents a 275 km long NE-SW section with 18 wells, and figure 6 presents a $625 \mathrm{~km}$ long SSE-NNW with 25 wells. All sections cross the entire lateral extent of Lower and Middle Triassic strata of the subsurface of the WCSB. Along these sections, the study interval lay stratigraphically above the Permian Belloy Formation. In the eastern part of the basin, the studied interval is truncated either by the unconformable Jurassic Gordondale Formation or by the Upper Triassic Coplin unconformity, whereas in the western part, it is capped by the late Middle to Upper Triassic (late Ladinian to Carnian) Charlie Lake Formation. In the present study, all sections are flattened on sequence boundary 4 (SB4).

The stratigraphic architecture illustrated on these cross-sections suggests that sequences 1,2 and 3 were only sourced from the east and south, whereas sequence 4 includes sediment sourced from the west and/or south-west. On all well sections: 1) sequence 1 is almost completely preserved except in eastern-most regions; 2 ) the proximal parts of sequence 2 are missing due to the sub-Jurassic, SB4, and SB3 erosional unconformities; 3 ) sequence 3 is preserved solely in the deepest part of the basin where it only presents distal deposits below an erosional truncation; and 4) sequence 4 is well preserved in the western part of the basin. 
On all sections, it appears that the maximum flooding surface of sequence 2 (MFS2) resulted from a

stronger backstep of the shoreline than the MFS of sequence 1 (MFS1), as only the distal part of the transgressive systems tract (TST2) is preserved. Above MFS2, it appears that the basin experienced a major regression trend up to SB4. In cycle A (Montney and Sunset Prairie formations), the secondorder MFS is, therefore, interpreted to be MFS2. As cycle B is only composed of sequence 4 , the maximum backstep of the sedimentary system is, therefore, recorded during MFS4.

\section{Groundbirch area facies section}

Figure 7 provides a detailed correlation of the TST4 and HST4 succession (upper part of the study interval) from the Groundbirch area in British Columbia. Well log signatures were interpreted based on sedimentological descriptions of core from the subsurface of Alberta and outcrop from the Williston Lake area. Figure 7 shows that TST4 (parasequence 1) gets thinner toward the centre of the well section. In the regressive part of sequence 4, marine deposits identified from well logs are highlighted on this figure (in sedimentary parasequences 2 to 5 , thinning from the west to the east). In addition to this thickening toward the east, no fluviatile deposits were identified in the Middle Triassic (Doig and Halfway formations) interval.

\section{D stratigraphic evolution}

\section{Cycle A}

Figures 4-6 illustrate the stratigraphic evolution along three 2D profiles. Figure 8 shows the distribution of sedimentary deposits during the third-order systems tracts of cycle A (Montney and Sunset Prairie formations).

The maximum thickness of TST1 (up to $80 \mathrm{~m}$ ) occurs along the eastern part of the basin (Fig. 8 a) where it is primarily composed of foreshore to shoreface deposits. The maximum thickness of HST1 (Fig. 8 b), is located in the northern part of the basin, where thicknesses can locally reach up to 120 $\mathrm{m}$. The falling stage systems tract 1 (FSST1) (Fig. $8 \mathrm{c}$ ) is poorly developed and only preserved in the central part of the basin where it consists of massive turbiditic deposits (Crombez et al., 2016). 
The lowstand deposits of sequence 2 are preserved primarily in the central part of the basin (Fig. $8 \mathrm{~d}$ )

242 where fine-grained turbidites occur interbedded with offshore deposits (up to $90 \mathrm{~m}$ ). The North-

243 South depositional fairway, extending from the cordillera in the South to the LST2 depocentre in the

244 North, consists mainly of turbiditic channel and overbank deposits. This suggests that during this

245 lowstand period, a large part of the sedimentary input may have come from the South. In this

246 interval the turbidites are often associated with HCS and are, therefore, interpreted as shelf

247 turbidites. TST2 consists of starved deposits in the basin (Fig. 8 e). In our interpretation, based on

248 sequence stratigraphic principles, the area of maximum thickness was likely located a few kilometres

249 beyond the sub-Jurassic erosion edge to the east. HST2 records a significant progradation of the

250 sedimentary system (Fig. 8 f), from shoreface in the east to offshore toward the west. However, the

251 maximum thickness is still located in the southern and eastern parts of the basin and can reach up to

$252100 \mathrm{~m}$. Above HST2, the FSST2 is poorly preserved due to erosion by SB3 and SB4. In the basin, it can

253 locally reach $40 \mathrm{~m}$ in thickness (Fig. $8 \mathrm{~g}$ ).

254 Fig. 8 (h-k) presents the thickness of sequence 3. In this figure, it appears that most of the preserved 255 part of sequence 3 occurs below the SB4 level of erosion. The maximum thickness of LST3 (Fig. 8 h) is

256 located in the western part of the basin, along the deformation limit. Shoreface and offshore 257 deposits can reach thicknesses of up to $100 \mathrm{~m}$. In the present-day configuration, TST3 only presents, 258 offshore to offshore transition, starved sedimentation and is only preserved in the west-central part 259 of the basin (Fig. 8 i). Both HST3 and FSST3 (Figs. 8 j and $\mathbf{k}$ ) are also only preserved in the western 260 part of the basin, where mainly offshore to offshore transition deposits can reach thicknesses up to $26170 \mathrm{~m}$.

262 Figure 9 a presents isopach maps of the three third-order sequences within cycle A (Montney 263 Formation). It shows that these three sequences do not have the same areas of maximum sediment accumulation. During sequence 1, maximum accumulation occurred in the northern part and eastern margin of the basin. During sequence 2 , the maximum accumulation shifted to the central part of the basin. In sequence 3 , the depocentre of the preserved parts of the sedimentary succession is located 
in the western part of the basin. Fig. 9 a also illustrates the location of the main structural elements below the Triassic strata: the Hay River shear zone (HRSZ) and the inherited structure from the Palaeozoic Peace River Arch (PRA) collapse (The Leduc reef indicates the margin of the PRA, O'Connell, 1994; Switzer et al., 1994; Wright et al., 1994). On figure 9, it is apparent that the maximum thickness of sequence 1 occurs north of the HRSZ, while the maximum thickness of sequence 2 was deposited in the basin centre above the former PRA. Figure 9 shows that the preserved parts of sequence 3 are also located above the PRA. Based on the upscaling of the sedimentary facies into three broad depositional environments, Figure $\mathbf{9}$ b presents schematic paleogeographic maps of cycle A. The maps each represent a snapshot of the paleogeography at the end of the lowstand of each third-order sequence. Black arrows illustrate dominant sedimentary inputs from the north-east, the east and the south-east during deposition of cycle A (Fig. 9 b). These maps are built using the isopachs of the last systems tracts of each sequence. This assumes that the decrease of the sedimentary thickness coincides with the slope. It is therefore important to keep in mind when interpreting these maps that due to the spacing between the correlation lines, the maps only present a global view of the paleogeography and are unlikely to capture the high-resolution heterogeneities in the sedimentary system. In addition, as tidal and shoreface environments are laterally equivalent and their relative distribution in mainly controlled by the basin physiography and the wave activity, and are poorly preserved in this case study, they are gathered and presented as shallow deposits on these maps.

\section{Cycle B}

LST4 is not preserved in the subsurface of the WCSB (Fig. 10 a). Figure 10 a shows that the TST4 maximum thickness occurs in a halo shape with a maximum thickness of up to $40 \mathrm{~m}$. This figure also shows that during HST4 the maximum thickness is recorded along the present-day deformation limit in the western part of the basin, where the thickness can reach up to $225 \mathrm{~m}$. More proximal facies, and the thickening of this cycle near the deformation limit, suggests that sedimentary input was 
likely from the west as well as the east. Finally, evidence of large-scale structural controls on 293 depositional thickness are not observed (Fig. 10 a).

294 Reconstruction of the stratigraphic architecture of the Montney, Sunset Prairie, Doig, and Halfway

295 formations show that cycle A (Montney and Sunset Prairie formations) and cycle B (Doig and Halfway formations) are separated by a major erosional unconformity (also described by Golding et al., 2014; Furlong et al., 2018 a, b). In cycle A, the basin shows a progradation of the sedimentary system (observed from the evolution of the systems tracts depocentres) during the time interval between MFS2 and SB4. At the end of sequence 3, it appears that the basin experienced major subaerial exposure. Figure 10 b suggests a completely different paleogeography in cycle B compared to cycle A. Our interpretation suggests that during this cycle, the WCSB experienced sedimentary input from both the continent to the east as well as from a western source. Indeed, stratigraphic thicknesses and sedimentary facies (Fig. 7) suggest that sedimentary inputs during TST4 came from both the east and the west whereas during HST4 they may have been sourced primarily from the west (Fig. 7). Above SB4, stratigraphic correlations suggest that the basin was becoming increasingly restricted culminating in deposition of sabkha environments in the Charlie Lake Formation (Fig. 4-7).

\section{Mineralogy}

The results of the QEMSCAN analyses are presented in figure 11. On this figure, sequences are represented by different colours and symbols correspond to different wells which are representative of proximal and distal areas of the basin. Figure $\mathbf{1 1}$ a shows that in the study interval clay content is low (average of 14 wt. \%) but can reach up to $35 \mathrm{wt}$ \%. Quartz, feldspar, and mica (Q-F-M) are the dominant minerals (from 25 wt. \% to 80 wt. \% with an average of 55 wt. \%), carbonates represent 27 wt. \% on average (from 10 wt. \% to 70 wt. \%) (Fig. 11 a). Cycle B (Doig and Halfway formations; average Q-F-M = 52 wt. $\%$, clay $=8$ wt. $\%$ and carbonate $=40 \mathrm{wt} . \%$ ) has less clay and more carbonate than cycle A (Montney and Sunset Prairie formations; Q-F-M = 58 wt. \%, clay = 17 wt. \%; quartz 
versus carbonate $=25$ wt. \%) (Fig. 11 a). These QEMSCAN analyses show the occurrence of distinct mineral trends in cycles $\mathrm{A}$ and $\mathrm{B}$.

\section{DISCUSSION}

\section{Stratigraphic record, eustatic variations and regional geodynamic evolution}

In the present study, we highlight 4 stratigraphic sequences (Fig. 3). Three occur in the Montney Formation (sequences 1-3) and one in the Doig and Halfway formations (sequence 4). Previous studies on biostratigraphy (Orchard and Tozer, 1997; Orchard and Zonneveld, 2009; Golding et al., 2014, Golding et al., 2015 b; Henderson and Schoepfer, 2017; Henderson et al., 2018) provide a chronostratigraphic framework for these sequences. In the present work we chose to use $250.0 \mathrm{Ma}$ as the date of the boundary between the Induan and the Olenekian as suggested by Henderson et al. (2018). Based on the biostratigraphic data of these studies, the three sequences that were identified in the Montney and the recently defined Sunset Prairie formations are interpreted to have been deposited primarily during the Lower Triassic and the earliest Middle Triassic whereas the sequence encompassing the Doig, and Halfway formations (cycle B) were deposited primarily during the Middle Triassic.

To better calibrate the ages of the third-order sequences within the Montney Formation, Figure 12 a presents the high-frequency, global eustatic sea-level variations (Hardenbol et al., 1998). On Figure $12 \mathrm{a}$, this global curve presents three rise and fall cycles in the Lower Triassic and three in the Middle Triassic. In the present work, as no major basin scale hiatus was highlighted between sequence 1, 2 and 3 it is assumed that three high sea levels within the Lower Triassic present on Figure $\mathbf{1 2}$ a were approximately recorded in the stratigraphy by MFS1, 2 and 3 of our stratigraphic architecture (fig. 12 b). According to our interpretation of the stratigraphic architecture (fig. 12 c), sequence 2 and 3 represent respectively the HST and FSST of a second-order cycle A and major erosional surface SB4 corresponds to the subaerial sequence boundary underneath the second-order cycle B. Recent work on the Doig Phosphate Zone (Golding et al., 2015 b) concluded that deposition of this interval was 
diachronous, with early Anisian deposits in the west and middle Anisian deposits to the east of their study area. Stratigraphic correlation of the present study suggests that they are part of the same stratigraphic interval deposited across the late early Anisian to the middle Anisian. On figure $\mathbf{1 2} \mathbf{c}$, TST4 is interpreted to be linked to the long rise of sea level that is present in the late early to middle Anisian. As the last eustatic cycle recorded in cycle A ended in the earliest Anisian, the association of the high amplitude eustatic rise from the middle Anisian with the TST4 implies that a large part of the early Anisian eustatic cycle present on the curve was not recorded in the basin. In the present work, this unrecorded cycle (fig. $\mathbf{1 2}$ b) is interpreted to be the expression of the second-order LST of cycle B at the boundary between the Montney and Doig formations (fig. $\mathbf{1 2} \mathrm{c}$ ). This is supported by the fact that in the Williston lake area, a major unconformity incises down to sequence 2 and by the fact that in the WCSB, remnants of early Anisian marine sediments are preserved below the Doig Formation in the Sunset Prairie Formation, as discussed in Furlong et al. (2018 a and b). As TST4 (fig. 12 c) is interpreted as a second-order transgression, the Doig Phosphate Zone may have been deposited from the late early Anisian through the early upper Anisian. As one third order eustatic cycle is missing in the early Anisian, we suggest that a hiatus and a major erosion occurred at this time and that only a small fraction of early Anisian deposits are present in the preserved part of the basin. Above MFS4, the eustatic curve shows two episodes of relative sea level fall (Fig. 12 a). As in cycle A, the regression of the Middle Triassic cycle may consist of several third-order sequences. In the Anisian and Ladinian, no major cycle boundary was highlighted at basin-scale, but the two eustatic cycles may correspond to the two prograding cycles present in the Williston Lake area and elsewhere as reported in previous studies (Embry and Gibson, 1995; Davies et al., 1997; Embry, 1997, Gibson and Barclay, 1989).

Figure 12, summarizes our sequence stratigraphic interpretation of the Lower and Middle Triassic in western Canada. It shows that the global eustatic sea-level variations (Fig. 12 a, from Hardenbol et al., 1998) do not perfectly fit with our regional stratigraphic observations and interpretations from our study (fig. 12 b, c): (1) the highest sea level of cycle A does not coincide with MFS2 (interpreted 
as the second order MFS of this cycle), (2) the unrecorded cycle does not correspond to a major drop

368 of sea level, (3) cycle B shows two high-amplitude rises of the sea level. Misfit between the stratigraphic architecture of a basin and the depositional sequence described on the world eustatic curves has been observed by previous research in various case studies (e.g. Miall, 1986, 2009). As the Montney, Sunset Prairie, Doig, and Halfway formations consist primarily of marine deposits, relative variations of sea level registered in the sedimentary records result from global eustatic variations combined with regional tectonism impact. The misfit between the global eustatic variations and our stratigraphic framework suggests the strong influence of regional tectonics (e.g. regional uplift) on relative sea-level variations during the deposition of the Lower and Middle Triassic Strata. In order to investigate this structural control, we compute a composite relative eustatic curve fitting our interpretation, by adding two trends (a medium-term curve, with a period of $5.5 \mathrm{Ma}$ and an amplitude of ca. $35 \mathrm{~m}$ and a long-term curve, with an amplitude of ca. $25 \mathrm{~m}$, Fig. $12 \mathrm{~d}$ ) to the eustatic curves of Hardenbol et al. (1998). The periods and the amplitudes of these two curves were adjusted, in order to match the trends of the composite curve with the regional stratigraphic observations. As the basin underwent complex structural evolution (Rohais et al., 2018), those curves are interpreted to represent the impact of a small, continuous, continental uplift (long-term curve) and the footprint of regional geodynamics resulting in more punctual and transient structural regional uplift and subsidence (medium-term curve) on relative sea-level (Haq et al., 1987). On Fig. 12 d, it appears that the major lowstand conditions between cycle A and cycle B coincides with a minimum in the medium-term curve. This suggests that this sequence boundary was partly controlled by regional tectonic activity, likely the motion of western terranes (Beranek and Mortensen, 2011; Golding et al., 2015 a).

The integration of the stratigraphic architecture in global and regional eustatic variations supports that the geodynamic evolution of the study area and the related structural evolution of the basin 391 largely affected relative sea level and, therefore, partially controlled the stratigraphic architecture of Lower and Middle Triassic strata in the subsurface of the WCSB. 
394

395

396

397

398

The integration of the stratigraphic architecture in a chronostratigraphic framework shows that the three sequences (1-3) of the Montney and Sunset Prairie formations (cycle A) were deposited over approximately $5 \mathrm{Ma}$ whereas the single Middle Triassic cycle (cycle B) was deposited over more than $8 \mathrm{Ma}$. Isopach maps were used to compute the volume of sediment preserved in cycles A and B. In cycle $A, 44,000 \mathrm{~km}^{3}$ of sediments occur in the subsurface of Alberta and British Columbia whereas in cycle $B, 10,000 \mathrm{~km}^{3}$ are present. These volumes do not include any estimation of the parts that were eroded by the Jurassic (from cycles A and B) or the second-order cycle boundary between cycles A and B (from cycle A). Estimated average sediment fluxes in cycles A and B were computed based on preserved sediment volumes and cycle duration. It shows a major drop at the boundary between cycle $A$ and cycle $B$ (from $12,000 \mathrm{~km}^{3} / \mathrm{Ma}$ to $1,600 \mathrm{~km}^{3} / \mathrm{Ma}$ in cycle $B$, including a $30 \%$ increase of the volume to account for initial porosity and assuming no carbonate production). In detail, sequences 13 (cycle A) exhibits minimal variation in sediment flux (respectively 11,000, 18,000, and 7,900 $\mathrm{km}^{3} / \mathrm{Ma}$ ) considering that the top of sequence 3 was affected by the erosion of the SB4. Although figures 4-6 show that sub-Jurassic erosion is a major control on the preserved volumes of sediments, a drastic drop (one order of magnitude) of the sediment supply is likely to have happened at the cycle A - B boundary (from 12,000 to $1,600 \mathrm{~km}^{3} / \mathrm{Ma}$ ). Indeed, even if we consider that sub-Jurassic erosion removed half of cycle $B$, the average sedimentation rate of the cycle B (Doig Formation) would still be less than half the sedimentation rate of cycle A (Montney and Sunset Prairie formations).

During the Lower and Middle Triassic, the basin vas located approximately $30^{\circ} \mathrm{N}$. According to previous work on paleoclimates and atmospheric circulation on this interval, no climatic shifts are recorded as well as no seasonal influence (Hallam, 1985; Golonka et al., 1994; Davies, 1997 a; Davies et al., 1997; Sellwood and Valdes, 2006; Crombez et al., 2017 a), suggesting that the drop of sediment supply between cycles A and B is unlikely to be related to changes in the vegetation cover or increased runoff. Instead, we suggest this change in sedimentation rate is related to modifications 
of the continental scale physiography resulting in a decrease of the basin drainage area (Dai and Trenberth, 2002; Milliman and Meade, 1983).

421 The depocentre evolution for the different systems tracts from cycle $A$ together with the 422 paleoenvironmental reconstruction show that the major part of the sediment input comes from the 423 Canadian Shield (Fig. 9) which is consistent with previous stratigraphic evidence (Crombez et al., 2016; Euzen et al., 2018) that emphasized the progradation of the sedimentary system from east to west and also consistent with the occurrence of abundant ephemeral (Zonneveld et al., 2010) and rare perennial (Zonneveld and Moslow, 2014; 2018) deltas on the eastern margin of the basin during deposition of the Montney and Sunset Prairie formations (cycle A). In the Doig and Halfway formations, evidence presented in Golding et al. (2015 a) and Harris (2000) suggests sediment input from the west. In the present work, the 3D stratigraphic architecture of cycle B supports the occurrence of sedimentary sources from the west during the Middle Triassic (Figs. 7 and 10). Supporting this hypothesis, recent work (Playter et al., 2018; Morris et al. 2018) indicates that volcanic arc granite (VAG) or syn-collisional arc granite (SAG) contributed to the Lower and Middle Triassic sediment source including cratonic sources (e.g. the North American Craton). The integration 434 of their observations in recent work on the geodynamic settings on the basin in the Triassic (Rohais et al., 2018) suggests potential sources to the west. Indeed Rohais et al. (2018) emphasize a complex stacking of terranes to the west that are potential host for VAG or SAG.

Figure 7 shows thinning of proximal-marine deposits towards the east. This would be consistent with western-sourced sediment if continental successions (e.g. delta plain, flood plain, fluviatile) were present on the eastern edge of cycle B (Doig and Halfway formations). However, such facies were not encountered in core or outcrops either in this or previous studies. The thinning of marine units

441 towards the east is therefore more compatible with sediment sourced from the west. Here, it is 442 important to note that figure $\mathbf{7}$ indicates sources from the west but eastern sources are also likely to 443 be present during the deposition of cycle B (Halfway and Doig formations). 
Analyses of the stratigraphic architecture of cycles A and B emphasize a change of sedimentary sources between the Lower and Middle Triassic. It suggests a major reorganization of the regional paleogeography between the Montney and the Doig formations, during a time interval corresponding to LST4. This turnover is also highlighted by the mineralogy: cycle B contains more detrital carbonate than cycle A, which is consistent with a change of sediment sources (Fig. 11). Detailed analysis of the QEMSCAN results shows that the increase in carbonate content is mainly controlled by the increased in dolomite (from $16 \mathrm{wt} \%$ in sequence 3 to $30 \mathrm{wt} \%$ in sequence 4) rather than by a variation in the calcite content ( $8 \mathrm{wt} \%$ in sequence 3 to $6 \mathrm{wt} \%$ in sequence 4 ). As Palaeozoic formations in Western Canada consist dominantly of carbonates (Price et al., 1972), the areas supplying lithic elements (Quartz, Feldspars and Micas) in Lower and Middle Triassic were most likely reaching the Canadian Shield (Burwarsh et al., 1994; Kent, 1994). Moreover, the occurrence of an increased proportion of detrital carbonates in cycle B (as suggested by Vaisblat et al., 2017 in cycle A) suggests a close proximity to the source as carbonates tend to be rapidly dissolved when eroded. These observations support the interpretation of a major change in basin physiography and in the size of the fluvial catchment area. This resulted in increased reworking of carbonate-dominated Palaeozoic formations to the east with an overall reduction in sediment input from the Canadian Shield associated with increasing sediment supply from newly elevated Palaeozoic formations to the west.

The variations of the sediment type and source are not compatible with a passive margin basin setting as suggested by Edwards et al. (1994) and Davies et al. (1997). The present study supports the interpretation (i.e. Ferri and Zonneveld, 2008; Rohais et al., 2018) that Middle Triassic formations were deposited in a basin that included western sedimentary sources. Based on detrital zircons, Golding et al. (2015 a) also suggested the occurrence of western sources and the deposition of the 


\section{Depocentres and structural settings}

471 For each sequence, the large-scale tectonic control on sedimentation can be assessed through the

472

473

474

475

476

477

478

479

480

481

482

483

484

485

486

487

488

489

490

491

492

493

494

spatial relationship between the major structural elements of the basin and the thickness distribution.

The HRSZ is reported to have been active during the Precambrian (Hoffman, 1987; Wright et al., 1994) and to have had minimal impact on Triassic strata (Sturrock and Dawson, 1990). Zonneveld and Moslow (2014) discussed the importance of the HRSZ in controlling perennial fluvial systems to the coastline (also discussed in Zonneveld and Moslow, 2018). As discussed herein, the location of the sequence 1 maximum thickness supports the hypothesis that the HRSZ increased local subsidence and thus influenced deposition of the Lowermost Triassic.

Numerous studies have focused on the relative movements of the PRA (Cant, 1988; Barclay et al., 1990; McMechan 1990; O'Connell et al., 1990; Ross, 1990; Eaton et al., 1999), and agreed that the PRA rose during the Precambrian and then started to collapse during the Carboniferous. Other studies have suggested that the Peace River embayment affected the depositon of the Uppermost Triassic deposits (Barclay et al., 1990; Gibson and Barclay, 1989; Davies et al., 1997; Moslow and Davies, 1997; Zonneveld and Moslow, 2014, 2018). In the present work, the maximum thickness of sequence 2 that occurs above the former PRA may suggest the occurrence of bathymetric heritage from the arch collapse. Here, three scenarios are possible: (1) a bathymetric low induced by subsidence of the Dawson Creek Graben Complex; however, even if the LST2 maximum thickness is located above this structure, sequence 1 does not show any thickening in this area, (2) an irregular bathymetry induced by differential compaction of the underlying formations and (3) variation of the subsiding area between sequences 1 and 2: the North of the basin (above the HRSZ) subsided during sequence 1 and the centre of the basin (above the former PRA) subsided during sequence 2 (Moslow and Zaitlin, 2008). Furthermore, detailed studies on systems tract thickness and evolution are needed in this area in order to differentiate between these options. 
Finally, it is apparent in figures $\mathbf{8}(\mathbf{h}-\mathbf{k})$, that the preserved part of sequence 3 is located above the PRA. The present work suggests that SB4 was induced by a regional uplift as no major lowstand conditions are described in the global eustatic variations (fig. 12 a). Preservation of sequence 3 above the PRA is thus interpreted to be related to reactivation of the ancient structures of the Dawson Creek Graben Complex during the uplift. This reactivation created differential subsidence that increased the preservation of sequence 3 within the Dawson Creek Graben Complex.

The integration of the structural framework of the area with the location of the main depocentres emphasizes that the structural setting during the deposition of the Lower and Middle Triassic strata in the WCSB was not quiescent and that the stratigraphic architecture is affected by pre-existing structures.

\section{Stratigraphic architecture of the Lower and Middle Triassic marine strata of western}

\section{Canada}

Integrating our stratigraphic observations and interpretations in a biostratigraphic and eustatic framework allows to suggest large-scale structural controls on the Lower and Middle Triassic strata of the western Canada sedimentary basin. In addition, it enable us to update the chronostratigraphic chart of this interval (fig. $\mathbf{1 2} \mathbf{~ g}$ ). It is important to note that the part of this figure under the hatched area is conceptual and based on the integration of this work with the world eustatic curves. Figure 12 g shows that (1) the Montney and Sunset Prairie formations and (2) the Doig and Halfway formations are two different second-order cycles separated by a major time gap (ca. $2 \mathrm{Ma}$ ) associated with both emersion and a major erosion event. In the Montney and Sunset Prairie formations, previous studies have suggested the occurrence of three sequences with a unique regressive trend (Embry and Gibson, 1995; Davies et al., 1997; Embry, 1997, Gibson and Barclay, 1989). In the present study, the Montney Formation appears to be a perfect example of third-order sequence imbrication in a second-order cycle where the terminology of Catuneanu et al. (2009) can be applied. The correlation of over 400 wells throughout the basin shows that the maximum flooding surface of the Montney 
and Sunset Prairie formations (cycle A) occurred in the second third-order sequence described. In sequence 1, TST1 occurred during a long and smooth rise of sea level resulting in the deposition of backstepping shoreface units (the G-sand of Panek, 2000). In sequence 2, a thick turbiditic interval was deposited during a lowstand in regional sea level (Fig. 12). Above SB4, the present work emphasizes the occurrence of estuarine successions (as previous suggested by Zonneveld et al., 2010 a, $2010 \mathrm{~b}$ and Zonneveld and Moslow, 2018 in the eastern part of the basin) that were deposited in incised valleys during LST4 (as observed on the Brown Hill outcrop, Fig. 1). Above SB4, the basin was influenced by sediment sources from both the east and the west. In the present study, the two distinct prograding cycles of the Middle Triassic are only highlighted in the Williston Lake outcrop and are not described in the basin due to the lack of detail in HST4. However, they are described in previous studies (Embry and Gibson, 1995; Davies et al., 1997; Embry, 1997, Gibson and Barclay, 1989) and, therefore, presented in figure 12.

\section{CONCLUSIONS AND PERSPECTIVES}

The 3D basin-scale stratigraphic architecture of Lower and Middle Triassic strata in the WCSB was reconstructed based on an extensive network of regional cross-sections and on previous studies. Regional surfaces across Alberta and British Columbia were defined and discussed with regard to the structural and geodynamical evolution of the continent. The key outcomes of this reconstruction are summarized here below:

- Lower and Middle Triassic strata in the WCSB are divided into two second-order cycles (A and B) that are separated by a major erosional surface.

- The limit between the two cycles records a major time gap. This approximately 2 Ma long subaerial exposure is interpreted to be linked to a regional uplift that was probably induced by the initiation of western terrane collisions.

- The first second-order cycle (Montney Formation) was sourced primarily from eastern, continent/craton sources, whereas the second one (Doig and Halfway formations) includes 
sedimentary inputs from both the continent and recently elevated western terranes. This turnover is associated with a major change in paleogeographic setting between cycle $A$ and cycle B.

- Deposition of Lower and Middle Triassic strata took place in a tectonically active basin. Observations and interpretations include: (1) the occurrence of regional uplifts, (2) significant sediment thickness changes across the HRSZ, (3) preservation of sequence 3 above the PRA, (4) changes in the paleogeography that induced changes in sedimentary sources. the evolution of western terranes.

Lower and Middle Triassic strata of western Canada were, therefore, deposited upon a complex structural framework that influenced the regional evolution of this sedimentary system. It is likely this control will also affect the distribution of sedimentary heterogeneities in this interval, impacting the exploration for both conventional and unconventional in this interval. Further studies on the high-resolution architecture (e.g. Euzen et al., 2018) and stratigraphic modelling (e.g. Crombez et al.,

5592017 b) of these formations are still required to further understand how this control affect the high560 resolution facies distribution within the defined sequences. In addition, 3D advance petroleum 561 system modelling (e.g. Ducros et al., 2017) is still required to fully integrate this high-resolution facies 562 distribution and assess the unconventional potential of the Montney and Doig formations. 
Acknowledgments go to all those who have contributed to this project: IFP Technologies (Canada) Inc., SGS Canada, the Alberta Energy regulator, the BC Oil and Gas Commission, the Geological Survey of Canada, to Schlumberger that provided Petrel academic licenses, and to CSIRO for supporting the corresponding author through writing and publication of this manuscript. L. Schoneveld and D. Dewhurst are also acknowledged for their diligent proofreading of this manuscript.

\section{FIGURE CAPTIONS}

Fig. 1. (a) Location of the study area and of the data available for this study (geological map from Reed et al., 2005, Triassic subcrop edges from Edwards et al., 1994; basin limits from Wright et al., 1994). (b) Chronostratigraphic chart of the Lower and Middle Triassic of the Western Canada Sedimentary Basin (Orchard and Zonneveld, 2009; Furlong et al., 2018 a b)

Fig. 2. Facies, major sedimentary environments, and their Gamma Ray patterns (modified from Crombez et al., 2016). (a) Reddish heterolithic siltstones and clays with anhydrite nodules, (b) wavyto flaser-bedded, heterolithic siltstones and sandstones with bidirectional current ripples, (c) bioclastic sandstones, (d) medium-grained sandstone, (e) wavy-bedded (concave), heterolithic siltstones and sandstone, (f) heterolithic siltstones and sandstones with climbing ripples, (g) wavybedded (convex), heterolithic siltstones and sandstones, and, (h) massive dark grey siltstones.

Fig. 3. Synthetic stratigraphic framework of the Lower and Middle Triassic formation. Four depositional sequences with their internal surfaces are highlighted with different colours. Note that reaching this vertical resolution is only possible using well data, onshore seismic data do not present such details. SP: Sunset Prairie Formation.

Fig. 4. SE-NW well section with stratigraphic correlations. Note that the average distance between wells is ca. $15 \mathrm{~km}$. Supplementary wells were added to the correlation to reduce the spacing in area where correlations were uncertain. On this figure, Gamma-ray log is coloured so that the low 
radioactive intervals appear in yellow and the highly radioactive intervals appear in dark grey. Location on figure 1.

589

590

591

592

593

594

595

596

597

598

599

600

601

602

603

604

605

606

607

608

609

610

611

Fig. 5. NE-SW well section with stratigraphic correlations. Note that the average distance between wells is ca. $15 \mathrm{~km}$. Supplementary wells were added to the correlation to reduce the spacing in area where correlations were uncertain. On this figure, Gamma-ray log is coloured so that the low radioactive intervals appear in yellow and the highly radioactive intervals appear in dark grey. Location on figure 1.

Fig. 6. SSE-NNW well section with stratigraphic correlations. Note that the average distance between wells is ca. $25 \mathrm{~km}$. Supplementary wells were added to the correlation to reduce the spacing in area where correlations were uncertain. On this figure, Gamma-ray log is coloured so that the low radioactive intervals appear in yellow and the highly radioactive intervals appear in dark grey. Location on figure 1.

Fig. 7. Stratigraphic architecture and facies distribution in cycle B over the Groundbirch area. Note this section is $94 \mathrm{~km}$ long and has a well spacing $<9 \mathrm{~km}$. The cross section suggests western sediment sources during cycle B with a distal pinch-out of the marine deposits toward the east, combined with an eastward progradation. Detailed stratigraphic correlation shows a migration of the basin centre toward the east between TST4 and HST-FSST4. Location on figure 1. CL: Charlie Lake Formation.

Fig. 8. Thickness evolution for each identified systems tract within sequences 1,2 , and 3 (50 m isocontours). On this figure, the Leduc Reef trend highlights the extent of the former PRA and, therefore, the limit of the Palaeozoic Dawson Creek Graben Complex. This figure highlights the links between the depocentres and the inherited structural elements.

Fig. 9. (a) Thickness evolution in each systems tract in cycle A; (b) Paleogeographic maps of cycle A. (structural elements from Berger et al., 2008 and Leduc trend from Switzer et al., 1994). On this figure "shallow marine to continental" areas gather shorefaces, tidal and non-marine environments. Note that the sedimentary inputs come from the continent to the east. 
612 Fig. 10. (a) Thickness evolution in each systems tract in cycle B; (b) Paleogeographic maps of cycle B.

613 (structural elements from Berger et al., 2008 and Leduc trend from Switzer et al., 1994). On this

614 figure, "shallow marine" areas gather shorefaces and tidal environments. Note that no preserved

615 deposits are presented for LST4, it is interpreted to be a major erosion period across the basin at the

616 boundary between cycles A and B (ca. (1) Montney and (2) Doig and Halfway formations).

617 Fig. 11. Results of the QEMSCAN analyses. (a) Ternary diagram of the quartz-feldspar-mica (Q-F-M),

618 carbonates and clay content in the samples, (b) quartz versus carbonates cross plot of the analysed 619 samples. Note the two different trends between cycles A and B (ca. Montney and Sunset Prairie 620 formations and Doig and Halfway formations).

621 Fig. 12. Stratigraphic framework of the Lower and Middle Triassic strata of Western Canada 622 (modified from Davies et al., 1997). It presents (a) the global eustatic variations (from Hardenbol et 623 al., 1998), (b) the major stratigraphic observations and (c) interpretations from this work together 624 with the (d) long- and medium-term of a (e) composite eustatic variations curve that corresponds to 625 (f) the stratigraphic evolution. This is interpreted as a time gap between the deposition of cycles $A$ 626 and B. Note that on this figure the Induan - Olenekian boundary is placed at 250 Ma as suggested by 627 Henderson et al. (2018) while defined at 251.2 Ma by the ICS (Cohen et al., 2013). 
Armitage, J.H. 1962. Triassic Oil and Gas Occurrences in Northeastern British Columbia, Canada. Bulletin of Canadian Petroleum Geology, 10, 35-56.

Baby, G., Guillocheau, F., Boulogne, C., Robin, C. \& Dall'Asta, M. 2018. Uplift history of a transform continental margin revealed by the stratigraphic record: The case of the Agulhas transform margin along the Southern African Plateau. Tectonophysics, 731732, 104-130, https://doi.org/10.1016/j.tecto.2018.03.014.

Barclay, J.E., Krause, F.F., Campbell, R.I. \& Utting, J. 1990. Dynamic casting and growth faulting: Dawson Creek graben complex, Carboniferous-Permian Peace River embayment, western Canada. Bulletin of Canadian Petroleum Geology, 38, 115-145.

Beranek, L.P. \& Mortensen, J.K. 2011. The timing and provenance record of the Late Permian Klondike orogeny in northwestern Canada and arc-continent collision along western North America. Tectonics, 30, https://doi.org/10.1029/2010TC002849.

Berger, Z., Boast, M. \& Mushayandebvu, M. 2008. The contribution of integrated HRAM studies to exploration and exploitation of unconventional plays in North America. Reservoir, 35, 42-48.

Burwash, R.A., McGregor, C.R. \& Wilson, J. 1994. Precambrian basement beneath the Western Canada sedimentary basin. In: Mossop, G. D. \& Shetsen, I. (eds) Geological Atlas of the Western Canadian Sedimentary Basin. CSPG and Alberta Research Council, 49-56.

Butcher, G.S., Kendall, A.C., Boyce, A.J., Millar, I.L., Andrews, J.E. \& Dennis, P.F. 2012. Age determination of the Lower Watrous red-beds of the Williston Basin, Saskatchewan, Canada. Bulletin of Canadian Petroleum Geology, 60, 227-238, https://doi.org/10.2113/gscpgbull.60.4.227.

Cant, D.J. 1988. Regional structure and development of the Peace River Arch, Alberta: A Paleozoic failed-rift system? Bulletin of Canadian Petroleum Geology, 36, 284-295.

Carlson, C.E. 1968. Triassic-Jurassic of Alberta, Saskatchewan, Manitoba, Montana, and North Dakota. AAPG Bulletin, 52, 1969-1983.

Catuneanu, O. 2006. Principles of Sequence Stratigraphy. Elsevier.

Catuneanu, O., Abreu, V., et al. 2009. Towards the standardization of sequence stratigraphy. Earth-Science Reviews, 92, 1-33, https://doi.org/10.1016/j.earscirev.2008.10.003.

Cohen, K.M., Finney, S.C., Gibbard, P.L. \& Fan, J.-X. 2013. The ICS International Chronostratigraphic Chart, https://doi.org/10.1111/j.1502-3931.1980.tb01026.x. 
Contreras, J., Zühlke, R., Bowman, S. \& Bechstädt, T. 2010. Seismic stratigraphy and subsidence analysis of the southern Brazilian margin (Campos, Santos and Pelotas basins). Marine and Petroleum Geology, 27, 1952-1980, https://doi.org/10.1016/j.marpetgeo.2010.06.007.

Crombez, V., Rohais, S., Baudin, F., Chauveau, B., Euzen, T. \& Granjeon, D. 2017. Controlling factors on source rock development: implications from 3D stratigraphic modeling of Triassic deposits in the Western Canada Sedimentary Basin. Bulletin de la Société géologique de France, 188, 30, https://doi.org/10.1051/bsgf/2017188.

Crombez, V., Baudin, F., et al. 2017. Basin scale distribution of organic matter in marine finegrained sedimentary rocks: Insight from sequence stratigraphy and multi-proxies analysis in the Montney and Doig formations. Marine and Petroleum Geology, 83, 382401, https://doi.org/10.1016/j.marpetgeo.2016.10.013.

Crombez, V., Rohais, S., Baudin, F. \& Euzen, T. 2016. Facies, well-log patterns, geometries and sequence stratigraphy of a wave-dominated margin: Insight from the Montney Formation (Alberta, British Columbia, Canada). Bulletin of Canadian Petroleum Geology, 64, 516-537, https://doi.org/10.2113/gscpgbull.64.4.516.

Cumming, A.D. 1956. The Watrous strata in Saskatchewan. In: First International Williston Basin Symposium. North Dakota Geol. Society and Saskatchewan Geol. Soc., 165-169.

Dai, A. \& Trenberth, K.E. 2002. Estimates of Freshwater Discharge from Continents: Latitudinal and Seasonal Variations. Journal of Hydrometeorology, 3, 660-687, https://doi.org/10.1175/1525-7541(2002)003<0660:EOFDFC>2.0.CO;2.

Davies, G.R. 1997. The Triassic of the Western Canada Sedimentary Basin: Tectonic and Stratigraphic Framework, Paleogeography, Paleoclimate and Biota. Bulletin of Canadian Petroleum Geology, 45, 434-460.

Davies, G.R., Moslow, T.F. \& Sherwin, M.D. 1997. The Lower Triassic Montney Formation, West-Central Alberta. Bulletin of Canadian Petroleum Geology, 45, 474-505.

Dixon, J. 2000. Regional Lithostratigraphic Units in the Triassic Montney Formation of Western Canada: GEOLOGICAL NOTE. Bulletin of Canadian petroleum geology, 48, 8083.

Ducros, M., Sassi, W., Vially, R., Euzen, T. \& Crombez, V. 2017. 2-D Basin Modeling of the Western Canada Sedimentary Basin across the Montney-Doig System: Implications for Hydrocarbon Migration Pathways and Unconventional Resources Potential. 117-134, https://doi.org/10.1306/13602027M1143703.

Eaton, D.W., Ross, G.M. \& Hope, J. 1999. The rise and fall of a cratonic arch: A regional seismic perspective on the Peace River Arch, Alberta. Bulletin of Canadian petroleum geology, 47, 346-361. 
Edwards, D.E., Barclay, J.E., Gibson, D.W., Kvill, G.E. \& Halton, E. 1994. Triassic Strata of the Western Canada Sedimentary Basin. In: Mossop, G. D. \& Shetsen, I. (eds) Geological Atlas of the Western Canada Sedimentary Basin. CSPG and Alberta Research Council, 259-273.

Embry, A.F. 1997. Global Sequence Boundaries of the Triassic and Their Identification in the Western Canada Sedimentary Basin. Bulletin of Canadian Petroleum Geology, 45, 415433.

Embry, A.F. \& Gibson, D.W. 1995. TR sequence analysis of the Triassic succession of the Western Canada Sedimentary Basin. In: Geological Survey of Canada, Open File 3058. 25-28.

Euzen, T., Moslow, T.F., Crombez, V. \& Rohais, S. 2018. Regional stratigraphic architecture of the Spathian Deposits in Western Canada - Implications for the Montney Resource Play T. Euzen, Moslow, T. F. \& M. Caplan (eds). Bulletin of Canadian Petroleum Geology, 66, 175-192.

Evoy, R.W. 1995. The Role of Sediment Bypassing in Siliciclastic Facies Variability on the Continental Shelf: Examples from the Fraser River Delta Foreslope and the Middle Triassic Doig Formation. PhD Thesis, University of Alberta.

Evoy, R.W. 1997. Lowstand Shorefaces in the Middle Triassic Doig Formation: Implications for Hydrocarbon Exploration in the Fort St. John Area, Northeastern British Columbia. Bulletin of Canadian Petroleum Geology, 45, 537-552.

Evoy, R.W. \& Moslow, T.F. 1995. Lithofacies associations and depositional environments in the Middle Triassic Doig Formation, Buick Creek Field, northeastern British Columbia. Bulletin of Canadian Petroleum Geology, 43, 461-475.

Ferri, F. \& Zonneveld, J.-P. 2008. Were Triassic rocks of the Western Canada Sedimentary Basin deposited in a foreland. Canadian Society of Petroleum Geologists Reservoir, 35, 12-14.

Furlong, C.M., Gegolick, A., et al. 2018a. Sedimentology and Ichnology of the Middle Triassic (Anisian) Sunset Prairie Formation of the Western Canada Sedimentary Basin T. Euzen, Moslow, T. F. \& M. Caplan (eds). Special Issue of Bulletin of Canadian Petroleum Geology, 66, 215-236.

Furlong, C.M., Gingras, M.K., Moslow, T.F. \& Zonneveld, J.-P. 2018b. The Sunset Prairie Formation: designation of a new Middle Triassic formation between the Lower Triassic Montney Formation and Middle Triassic Doig Formation in the Western Canada Sedimentary Basin, northeast British Columbia. Euzen, T., Moslow, T. F. \& Caplan, M. (eds). Bulletin of, 66, 193-214.

Gibson, D.W. 1975. Triassic Rocks of the Rocky Mountain Foothills and Front Ranges of Northeastern British Columbia and West-Central Alberta. Geological Survey of Canada, Bulletin 247.Gibson, D.W. \& Barclay, J.E. 1989. Middle Absaroka Sequence - The Triassic 
Stable Craton. Western Canada Sedimentary Basin - a Case History, Special Publication, 30, 219-232, https://doi.org/10.1037/0022-3514.84.2.377.

Gibson, D.W. 1974. Triassic Rocks of the Southern Canadian Rocky Mountains. Geological Survey of Canada, Bulletin 247.

Golding, M.L., Mortensen, J.K., Ferri, F., Zonneveld, J.-P. \& Orchard, M. 2015a. Determining the provenance of Triassic sedimentary rocks in northeastern British Columbia and western Alberta using detrital zircon geochronology, with implications for regional tectonics. Canadian Journal of Earth Sciences, 53, 140-155, https://doi.org/10.1139/cjes-2015-0082.

Golding, M.L., Mortensen, J.K., Zonneveld, J.P. \& Orchard, M.J. 2016. U-Pb isotopic ages of euhedral zircons in the Rhaetian of British Columbia: Implications for Cordilleran tectonics during the Late Triassic. Geosphere, https://doi.org/10.1130/GES01324.1.

Golding, M.L., Orchard, M.J., Zonneveld, J.-P., Henderson, C.M. \& Dunn, L. 2014. An exceptional record of the sedimentology and biostratigraphy of the Montney and Doig formations in British Columbia. Bulletin of Canadian Petroleum Geology, 62, 157-176.

Golding, M.L., Orchard, M.J., Zonneveld, J.-P. \& Wilson, N.S.F. 2015b. Determining the age and depositional model of the Doig Phosphate Zone in northeastern British Columbia using conodont biostratigraphy. Bulletin of Canadian Petroleum Geology, 63, 143-170.

Golonka, J., Ross, M.I. \& Scotese, C.R. 1994. Phanerozoic paleogeographic and paleoclimatic modeling maps. In: Pangea: Global Environments and Resources. CSPG Special Publications.

Gottlieb, P., Wilkie, G., et al. 2000. Using quantitative electron microscopy for process mineralogy applications. JOM, 52, 24-25, https://doi.org/10.1007/s11837-000-0126-9.

Grimaud, J.L., Rouby, D., Chardon, D. \& Beauvais, A. 2018. Cenozoic sediment budget of West Africa and the Niger delta. Basin Research, https://doi.org/10.1111/bre.12248.

Guillocheau, F., Chelalou, R., et al. 2015. Cenozoic landscape evolution in and around the Congo Basin: Constraints from sediments and planation surfaces. In: Geology and Resource Potential of the Congo Basin. 1-417., https://doi.org/10.1007/978-3-64229482-2_14.

Guillocheau, F., Rouby, D., Robin, C., Helm, C., Rolland, N., Le Carlier de Veslud, C. \& Braun, J. 2012. Quantification and causes of the terrigeneous sediment budget at the scale of a continental margin: A new method applied to the Namibia-South Africa margin. Basin Research, 24, 3-30, https://doi.org/10.1111/j.1365-2117.2011.00511.x.

Hallam, A. 1985. A review of Mesozoic climates. Journal of the Geological Society, 142, 433445, https://doi.org/10.1144/gsjgs.142.3.0433. 
Haq, B.U., Hardenbol, J. \& Vail, P.R. 1987. Chronology of Fluctuating Sea Levels Since the Triassic. Science, 235, 1156-1167, https://doi.org/10.1126/science.235.4793.1156.

Hardenbol, J., Thierry, J., Farley, M., Jacquin, T., De Graciansky, P.C. \& Vail, P.R. 1998. Mesozoic and Cenozoic Sequence Chronostratigraphic Framework of European Basins. In: P.-C.D. Graciansky, J. Hardenbol, T. J. and P. R. V. (ed.) European Basins. In Mesozoic and Cenozoic Sequence Stratigraphy of European Basins. Special Publications of SEPM $\mathrm{N}^{\circ} 60,3-13$.

Harris, R.G. 2000. Triassic Doig Formation Sand Bodies in the Peace River Area of Western Canada : Depositional and Structural Models, and the Impact of Diagenesis on Reservoir Properties. MSc Thesis, University of British Columbia., https://doi.org/10.1007/s13398014-0173-7.2.

Helland-Hansen, W. \& Gjelberg, J.G. 1994. Conceptual basis and variability in sequence stratigraphy: a different perspective. Sedimentary Geology, 92, 31-52, https://doi.org/10.1016/0037-0738(94)90053-1.

Helland-Hansen, W. \& Hampson, G.J. 2009. Trajectory analysis: concepts and applications. Basin Research, 21, 454-483, https://doi.org/10.1111/j.1365-2117.2009.00425.x.

Helland-Hansen, W. \& Martinsen, O.J. 1996. Shoreline trajectories and sequences; description of variable depositional-dip scenarios. Journal of Sedimentary Research, 66, 670-688, https://doi.org/10.1306/D42683DD-2B26-11D7-8648000102C1865D.

Henderson, C.M., Golding, M.L. \& Orchard, M.J. 2018. Conodont Sequence Biostratigraphy of the Lower Triassic Montney Formation Euzen, T., Moslow, T. F. \& M. Caplan (eds). Special Issue of Bulletin of Canadian Petroleum Geology, 66, 7-22.

Henderson, C.M. \& Schoepfer, S.D. 2017. High-Resolution Biostratigraphic and XRF585 Geochemical Correlation of the Montney Formation, NEBC. In: CSPG CSEG CWLS Join Annual Convention. Calgary.

Hoffman, P.F. 1987. Continental transform tectonics: Great Slave Lake shear zone (ca. 1.9 Ga), northwest Canada. Geology, 15, 785-788, https://doi.org/10.1130/00917613(1987)15.

Hunt, D. \& Tucker, M.E. 1992. Stranded parasequences and the forced regressive wedge systems tract: deposition during base-level fall-reply. Sedimentary Geology, 95, 147160, https://doi.org/10.1016/0037-0738(94)00123-C.

Kendall, D.R. 1999. Sedimentology and Stratigraphy of the Lower Triassic Montney Formation, Peace River Basin, Subsurface of Northwestern Alberta. MSc Thesis, University of Calgary.

Kent, D.M. 1994. Paleogeographic evolution of the cratonic platform-Cambrian to Triassic. In: Shetsen, G. M. and I. (ed.) Geological Atlas of the Western Canada Sedimentary Basin, G. Mossop and I. Shetsen, Compilers, Canadian Society of Petroleum Geologists 
and Alberta Research Council, Special Report. CSPG and Alberta Research Council, 6986.

Leroux, E., Rabineau, M., et al. 2017. High-resolution evolution of terrigenous sediment yields in the Provence Basin during the last $6 \mathrm{Ma}$ : relation with climate and tectonics. Basin Research, 29, 305-339, https://doi.org/10.1111/bre.12178.

Markhasin, B. 1997. Sedimentology and Stratigraphy of the Lower Triassic Montney Formation, Subsurface of Northwestern Alberta. MSc Thesis, University of Calgary.

Martinsen, O.J., Sømme, T.O., Thurmond, J.B., Helland-Hansen, W. \& Lunt, I. 2010. Sourceto-sink systems on passive margins: theory and practice with an example from the Norwegian continental margin. In: Petroleum Geology: From Mature Basins to New Frontiers-Proceedings of the 7th Petroleum Geology Conference. 913-920., https://doi.org/10.1144/0070913.

Matenco, L., Andriessen, P., et al. 2013. Quantifying the mass transfer from mountain ranges to deposition in sedimentary basins: Source to sink studies in the Danube basin-black sea system. Global and Planetary Change, 103, 1-18, https://doi.org/10.1016/j.gloplacha.2013.01.003.

McMechan, M.E. 1990. Upper Proterozoic to Middle Cambrian history of the Peace River arch: evidence from the Rocky Mountains. Bulletin of Canadian Petroleum Geology, 38, 36-44.

Miall, A.D. 1986. Eustatic sea level changes interpreted from seismic stratigraphy: a critique of the methodology with particular reference to the North Sea Jurassic record. American Association of Petroleum Geologists Bulletin, https://doi.org/10.1306/9488593A-1704-11D7-8645000102C1865D.

Miall, A.D. 2009. Correlation of sequences and the global eustasy paradigm: A review of current data. In: Geoconvention: Frontiers+ Innovation. 123-126.

Milliman, J.D. \& Meade, R.H. 1983. World-Wide Delivery of River Sediment to the Oceans. The Journal of Geology, 91, 1-21.

Monger, J. \& Price, R. 2002. The Canadian cordillera: Geology and Tectonic Evolution. CSEG Recorder, 27, 17-36.

Morris, N., Asgar-Deen, M., Gardner, D. \& Glemser, C. 2018. A Preliminary Investigation of the Igneous Origins of the Montney and Doig formations: Integrating Igneous Geochemistry Techniques for Interpreting Sedimentary Provenance. Bulletin of Canadian Petroleum Geology, 66, 161-174.

Moslow, T.F. \& Davies, G.R. 1997. Turbidite Reservoir Facies in the Lower Triassic Montney Formation, West-Central Alberta. Bulletin of Canadian Petroleum Geology, 45, 507-536. 
Moslow, T.F. \& Zaitlin, B.A. 2008. Tight Gas Reservoirs of the Western Canada Deep Basin. In: AAPG Annual Convention. San Antonio.

O'connell, S.C. 1994. Geological history of the Peace River arch. In: GD Mossop and I. Shetsen (ed.) Geological Atlas of the Western Canada Sedimentary Basin. CSPG and Alberta Research Council, 431-437.

O'Connell, S.C., Dix, G.R. \& Barclay, J.E. 1990. The origin, history, and regional structural development of the Peace River Arch, Western Canada. Bulletin of Canadian Petroleum Geology, 38, 4-24.

Onoue, T., Zonneveld, J.-P., Orchard, M.J., Yamashita, M., Yamashita, K., Sato, H. \& Kusaka, S. 2016. Paleoenvironmental changes across the Carnian/Norian boundary in the Black Bear Ridge section, British Columbia, Canada. Palaeogeography, Palaeoclimatology, Palaeoecology, 441, 721-733, https://doi.org/10.1016/j.palaeo.2015.10.008.

Orchard, M.J. \& Tozer, E.T. 1997. Triassic conodont biochronology, its calibration with the ammonoid standard, and a biostratigraphic summary for the Western Canada Sedimentary Basin. Bulletin of Canadian Petroleum Geology, 45, 675-692.

Orchard, M.J. \& Zonneveld, J.-P. 2009. The Lower Triassic Sulphur Mountain Formation in the Wapiti Lake area: lithostratigraphy, conodont biostratigraphy, and a new biozonation for the lower Olenekian (Smithian). Canadian Journal of Earth Sciences, 46, 757-790.

Panek, R. 2000. The Sedimentology and Stratigraphy of the Lower Triassic Montney Formation in the Subsurface of the Peace River Area, Northwestern Alberta. MSc Thesis, University of Calgary.

Playter, T., Corlett, H., et al. 2018. Clinoform identification and correlation in fine-grained sediments: A case study using the Triassic Montney Formation. Sedimentology, 65, 263302, https://doi.org/10.1111/sed.12403.

Posamentier, H.W. \& Walker, R.G. (eds). 2006. Facies Models Revisited. Special Publications of SEPM.

Power, M.R. \& Burns, S. 2013. The Comparison of QEMSCAN and XRD Analysis in the Mineralogical Characterisation of Unconventional Reservoirs: The Benefits of an Integrated Approach. In: CSPG CSEG CWLS Join Annual Convention. Calgary.

Price, R.A. 1994. Cordilleran tectonics and the evolution of the Western Canada Sedimentary Basin. In: Mossop, G. D. \& Shetsen, I. (eds) Geological Atlas of the Western Canada Sedimentary Basin. CSPG and Alberta Research Council, 13-24.

Price, R.A., Balkwill, H.R., Charlesworth, H.A.K., Cook, D.G. \& Simony, P.S. 1972. The Canadian Rockies and tectonic evolution of the southeastern Canadian Cordillera: 24th International Geological Congress. Guidebook for Excursion A15-C15, Geological Survey of Canada. 
Reed Jr., J.C., Wheeler, J.O. \& Tucholke, B.E. 2005. Decade of North American Geology Geologic Map of North America-Perspectives and Explanation, https://doi.org/10.1130/DNAG-CSMS-v1.1.

Rohais, S., Barrois, A., Colletta, B. \& Moretti, I. 2016. Pre-salt to salt stratigraphic architecture in a rift basin: insights from a basin-scale study of the Gulf of Suez (Egypt). Arabian Journal of Geosciences, 9, 24p, https://doi.org/10.1007/s12517-016-2327-8.

Rohais, S., Crombez, V., Euzen, T. \& Zonneveld, J.-P. 2018. Subsidence dynamics of the Montney Formation (Early Triassic, Western Canada Sedimentary Basin): insights for its geodynamic setting and wider implications Euzen, T., Moslow, T. F. \& Caplan, M. (eds). Bulletin of Canadian Petroleum Geology, 66, 128-160.

Ross, G.M. 1990. Deep crust and basement structure of the Peace River Arch region: constraints on mechanisms of formation. Bulletin of Canadian Petroleum Geology, 38, 25-35.

Rouby, D., Bonnet, S., et al. 2009. Sediment supply to the Orange sedimentary system over the last $150 \mathrm{My}$ : An evaluation from sedimentation/denudation balance. Marine and Petroleum Geology, 26, 782-794, https://doi.org/10.1016/j.marpetgeo.2008.08.004.

Sellwood, B.W. \& Valdes, P.J. 2006. Mesozoic climates: General circulation models and the rock record. Sedimentary Geology, 190, 269-287, https://doi.org/10.1016/j.sedgeo.2006.05.013.

Sturrock, D.L. \& Dawson, S.W. 1990. Ring/Border Field, Alberta and British Columbia. Oil and Gas Pools of Canada Series, 1.

Suter, E.H. 2006. Facies Models Revisited: Clastic Shelves. In: Posamentier, H. W. \& Walker, R. G. (eds) Facies Models Revisited. SEPM Special Publication N84, 339-398.

Switzer, S.B., Holland, W.G., et al. 1994. Devonian Woodbend-Winterburn strata of the Western Canada sedimentary basin. In: Shetsen, G. M. and I. (ed.) Geological Atlas of the Western Canada Sedimentary Basin. CSPG and Alberta Research Council, 165-202.

Vaisblat, N., Harris, N.B., DeBhur, C., Euzen, T., Gasparrini, M., Crombez, V., Rohais, S., Krause, F., Ayranci, K., 2017. Diagenetic model for the deep Montney Formation, northeastern British Columbia. Geoscience BC Summary of Activities 2016, Geoscience BC, Report 2017-1, 37-48.

Wright, G.N., McMechan, M.E. \& Potter, D.E.G. 1994. Structure and Architecture of the Western Canada Sedimentary Basin. In: Mossop, G. D. \& Shetsen, I. (eds) Geological Atlas of the Western Canada Sedimentary Basin. CSPG and Alberta Research Council, 25-40.

Zonneveld, J.-P. 2000. Sedimentology and Sequence Biostratigraphic Framework of a Mixed Siliciclastic-Carbonate Depositional System, Middle Triassic, Northeastern British Columbia. PhD Thesis, University of Alberta. 
Zonneveld, J.-P. 2001. Middle Triassic biostromes from the Liard Formation, British Columbia, Canada: oldest examples from the Mesozoic of NW Pangea. Sedimentary Geology, 145, 317-341.

Zonneveld, J.-P., Gingras, M.K. \& Beatty, T.W. 2010. Diverse ichnofossil assemblages following the PT mass extinction, Lower Triassic, Alberta and British Columbia, Canada: evidence for shallow marine refugia on the northwestern coast of Pangaea. Palaios, 25, 368-392.

Zonneveld, J.-P., Gingras, M.K. \& Pemberton, S.G. 2001. Trace fossil assemblages in a Middle Triassic mixed siliciclastic-carbonate marginal marine depositional system, British Columbia. Palaeogeography, Palaeoclimatology, Palaeoecology, 166, 249-276.

Zonneveld, J.-P., MacNaughton, R.B., Utting, J., Beatty, T.W., Pemberton, S.G. \& Henderson, C.M. 2010. Sedimentology and Ichnology of the Lower Triassic Montney Formation in the Pedigree-Ring/Border-Kahntah River Area, Northwestern Alberta and Northeastern British Columbia. Bulletin of Canadian Petroleum Geology, 58, 115-140.

Zonneveld, J.-P. \& Moslow, T.F. 2014. Perennial River Deltas of the Montney Formation: Alberta and British Columbia Subcrop Edge. In: Geoconvention: Focus.

Zonneveld, J.-P. \& Moslow, T.F. 2018. Palaeogeographic setting, Lithostratigraphy, and Sedimentary Framework of the Lower Triassic Montney Formation of western Alberta and northeastern British Columbia Euzen, T., Moslow, T. F. \& Caplan, M. (eds). Bulletin of Canadian Petroleum Geology.

Zonneveld, J.-P., Moslow, T.F. \& Henderson, C.M. 1997. Lithofacies associations and depositional environments in a mixed siliciclastic-carbonate coastal depositional system, upper Liard Formation, Triassic, northeastern British Columbia. Bulletin of Canadian Petroleum Geology, 45, 553-575. 


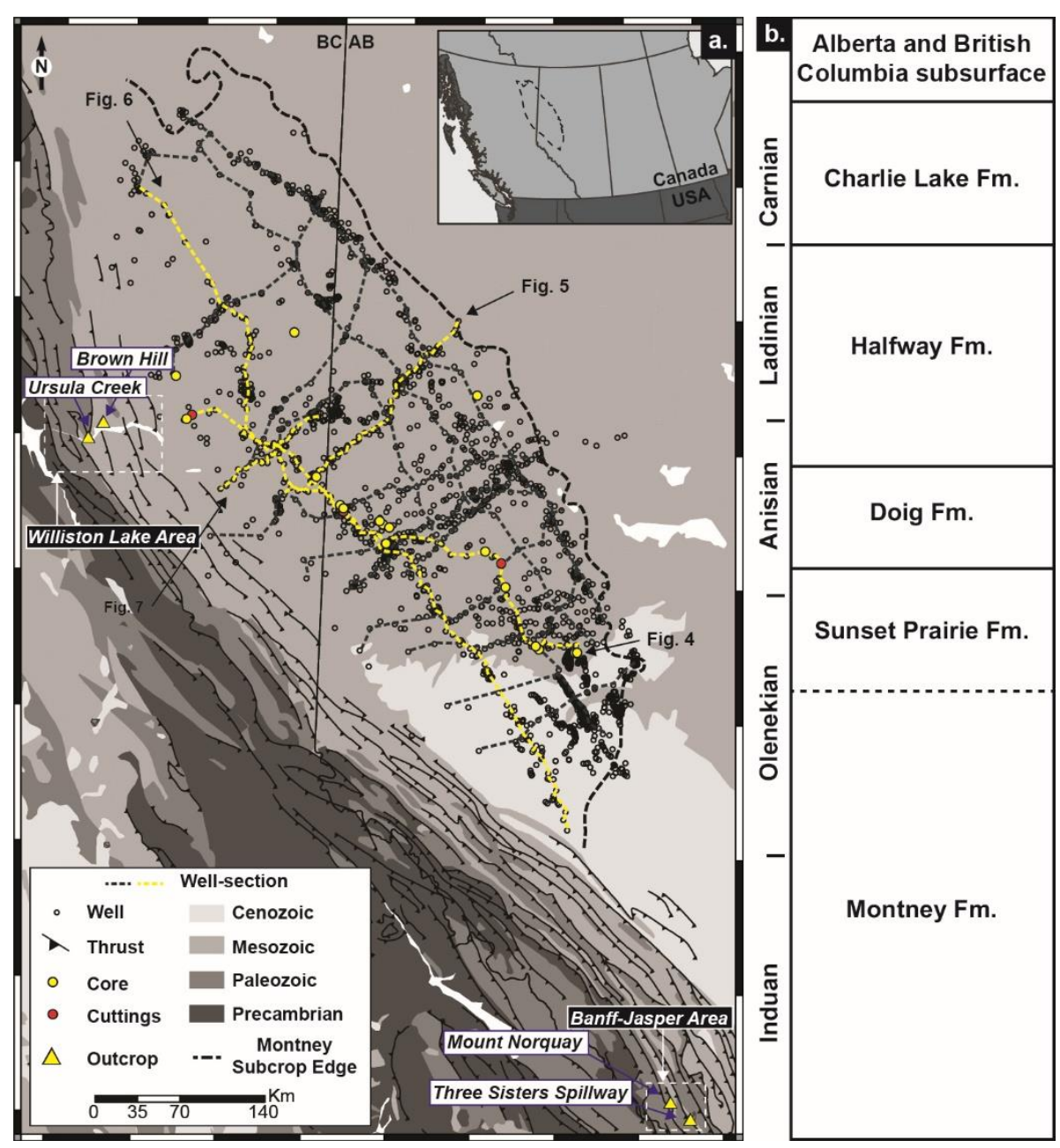

Figure 1 

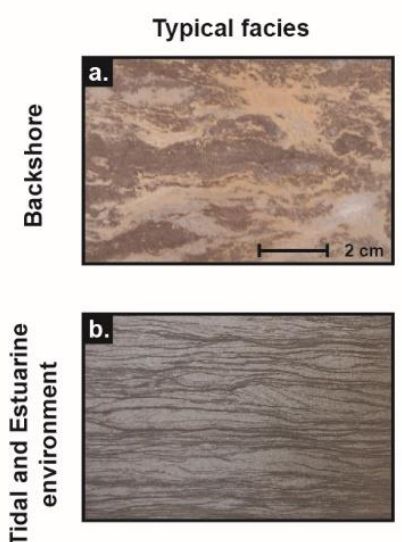

Mainly composed of light-brown to beige heterolithic fine- to medium-grained sandstones and dark-grey to brown heterolithic siltstone.

Presence of large-scale sigmoidal cross-stratifications as well as mud drapes. Common unidirectional current ripples and bidirectional ripples in siltstones and shales. Common trough cross-stratification in m-scale sandstone beds. Rare wavy ripples, soft sediment deformation and bioturbation.

Occasional gutters and basal erosional surfaces associated with layers of shell fragment.

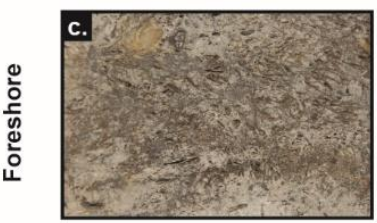

Mainly composed of light-grey to light-brown coarse-grained bioclastic sandstones organized in $\mathrm{dm}$ - to $\mathrm{m}$-scale intervals.

Base is often erosive.

Bioclasts are commonly monospecific composed of imbricated inarticulated lingulid brachiopods.

May feature low angle cross-stratification and wavy bedding.

Occasional muddy layers locally preserved.
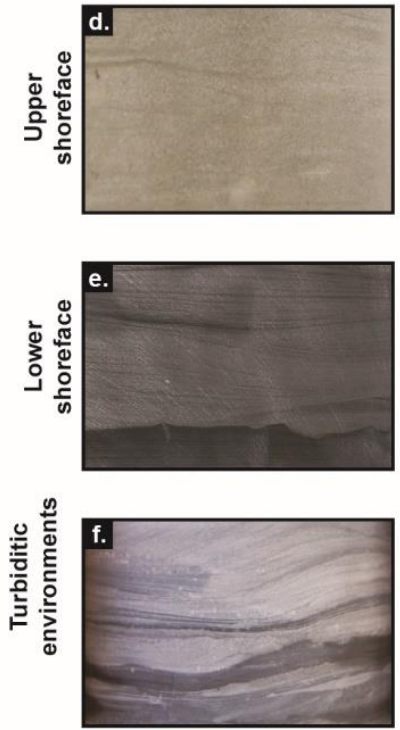

Composed of erosively-based, massive, light-brown, fine-grained sandstones erosively-based planar- to wavy-bedded, dark- to medium-grey, fine-grained sandstones and siltstones.

Common unidirectional current ripples, climbing ripples and a fining upward trend.

May present rare pyritized intervals in the fine interval, sparse bioturbation and thickening upward trend in massive fine-grained sandstones.

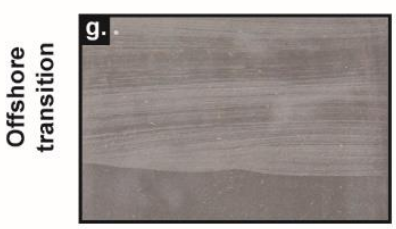

Composed of wavy- to planar-bedded, dark-grey, heterolithic fine-grained sandstones and siltstones.

Common sedimentary structures include hummocky cross-stratification, erosional bases, fining-upward trends and wavy bedded layers Rare sub-massive dark-grey siltstones and pyrite layers.

Bioturbation is common.

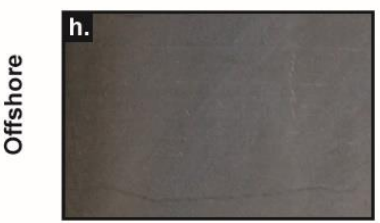

Mainly composed of massive to planar-laminated dark grey siltstones Common pyritized intervals.

May contain phosphatic debris or phosphate nodules as well as organic matter.
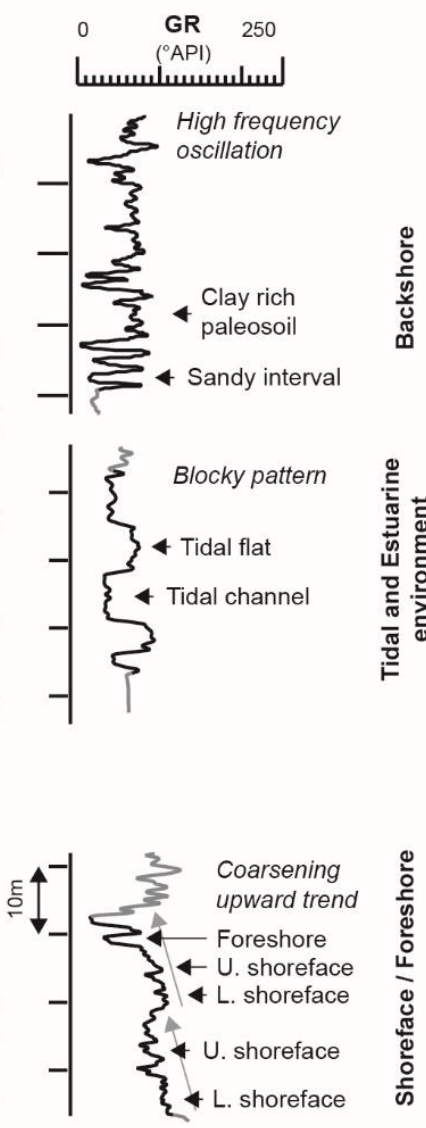
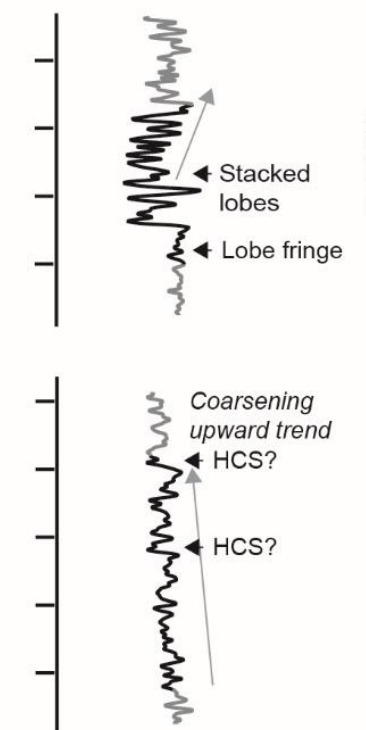

Figure 2 


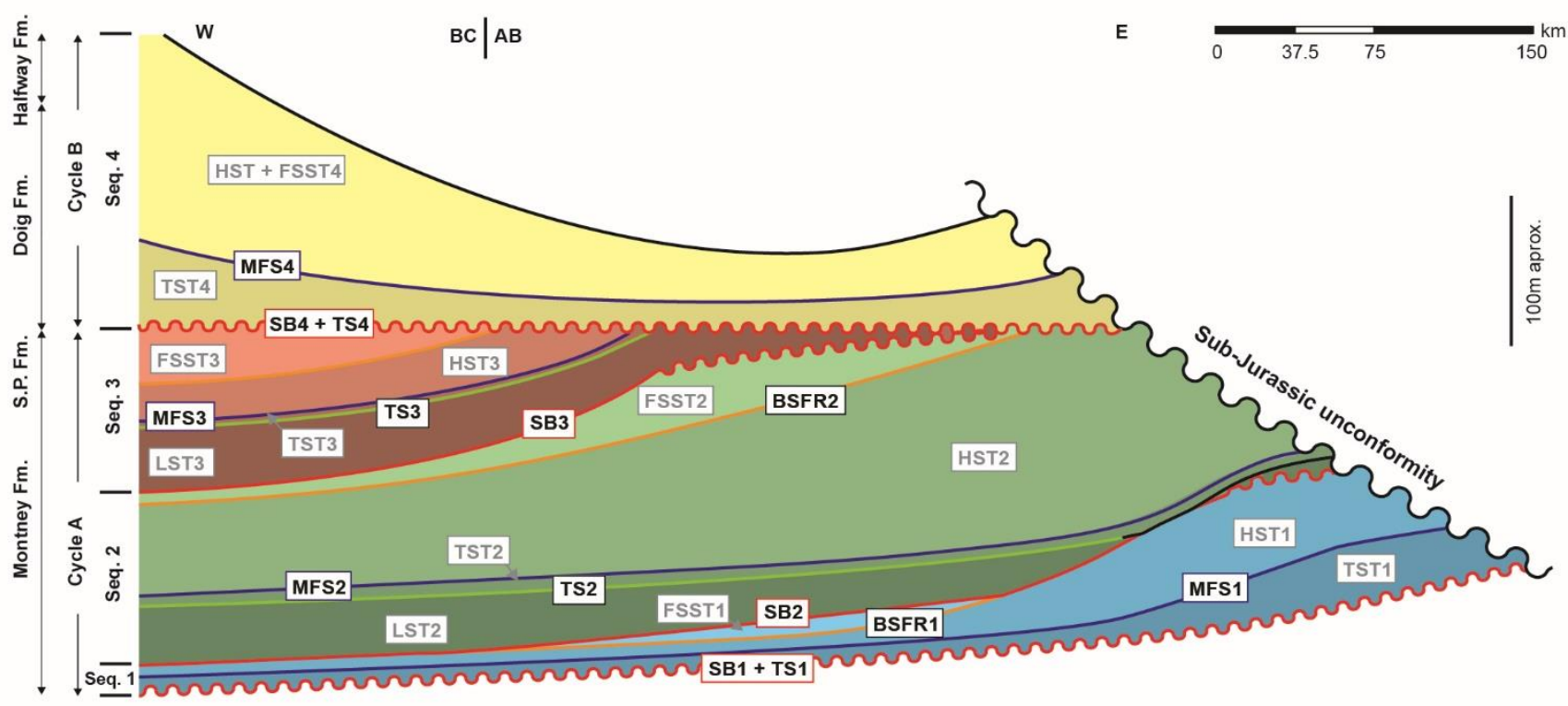

Major stratigraphic surfaces

Interpreted sequence Seq. 1 Seq. 2 Seq. 3 Seq. 4

- Basal Surface of forced regression (BSFR)

Falling stage systems tract (FSST)

Highstand systems tract (HST)

Maximum Flooding Surface (MFS)

Sequence Boundary (SB)

- Transgressive Surface (TS)

Transgressive systems tract (TST)

? Erosional surface

Lowstand systems tract (LST)

Figure 3 


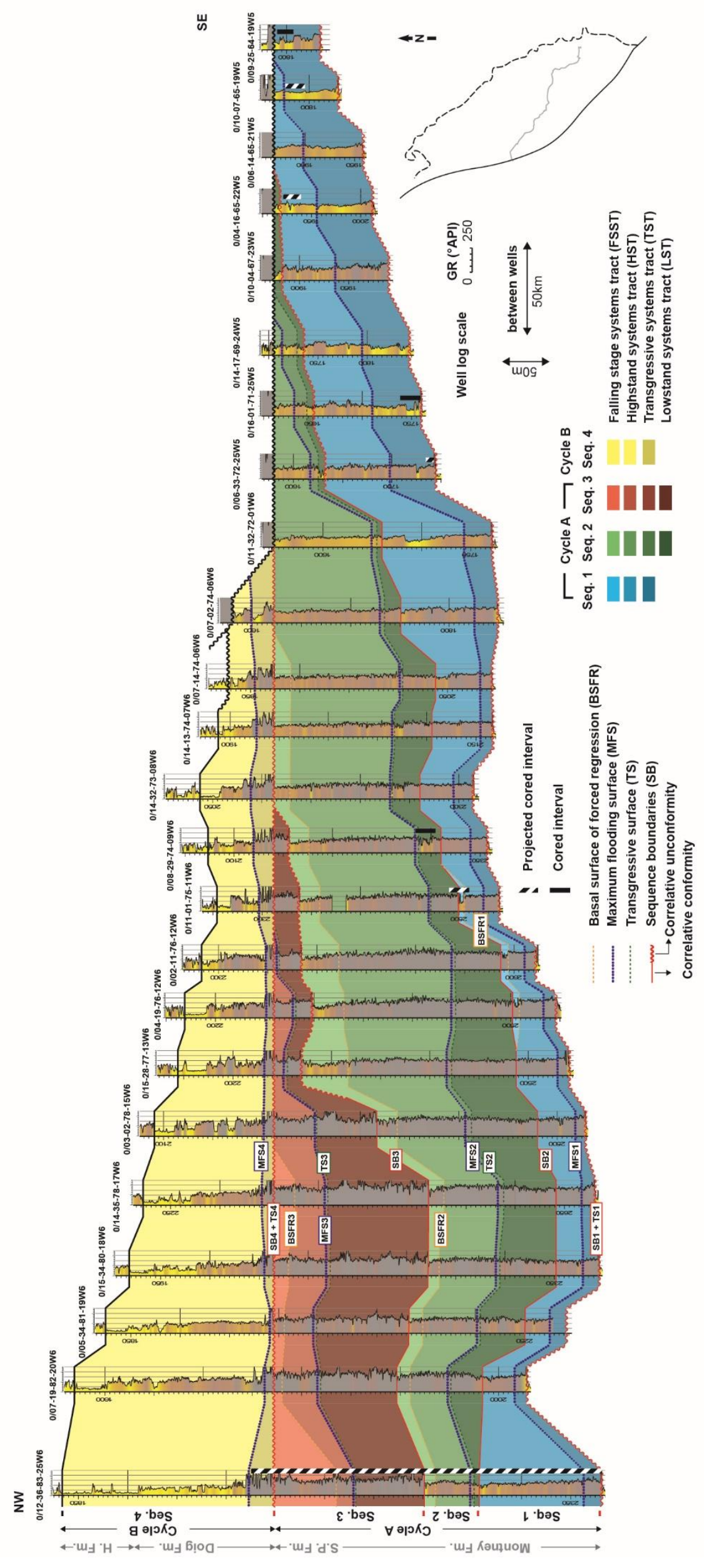

Figure 4 

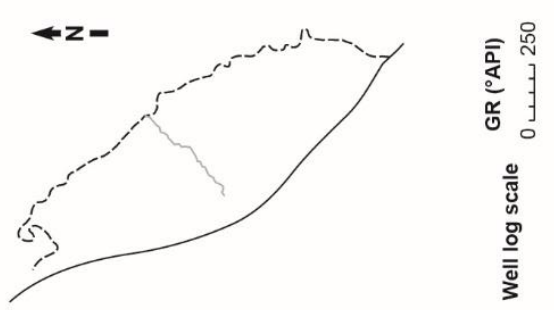

뜬
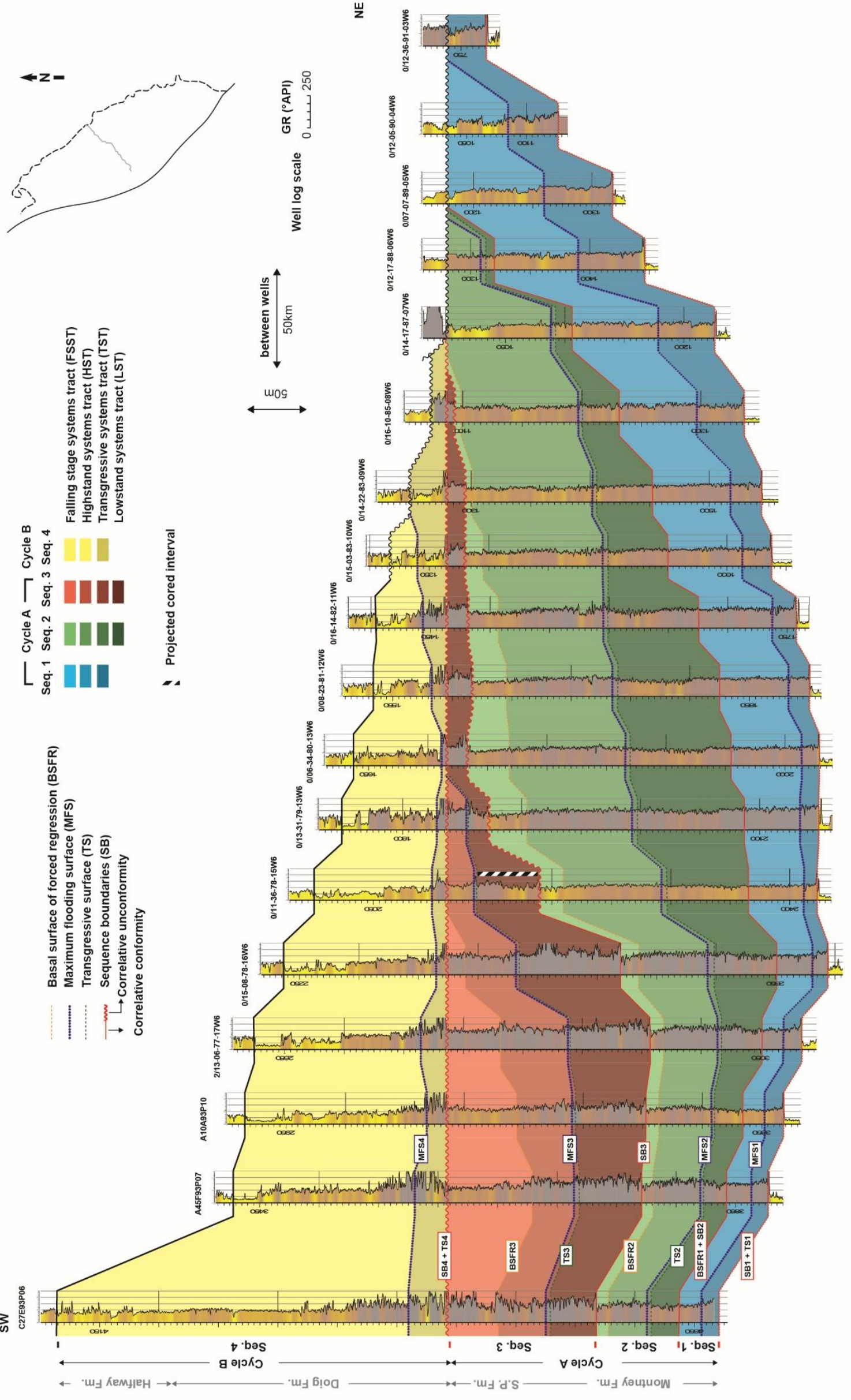

Figure 5 


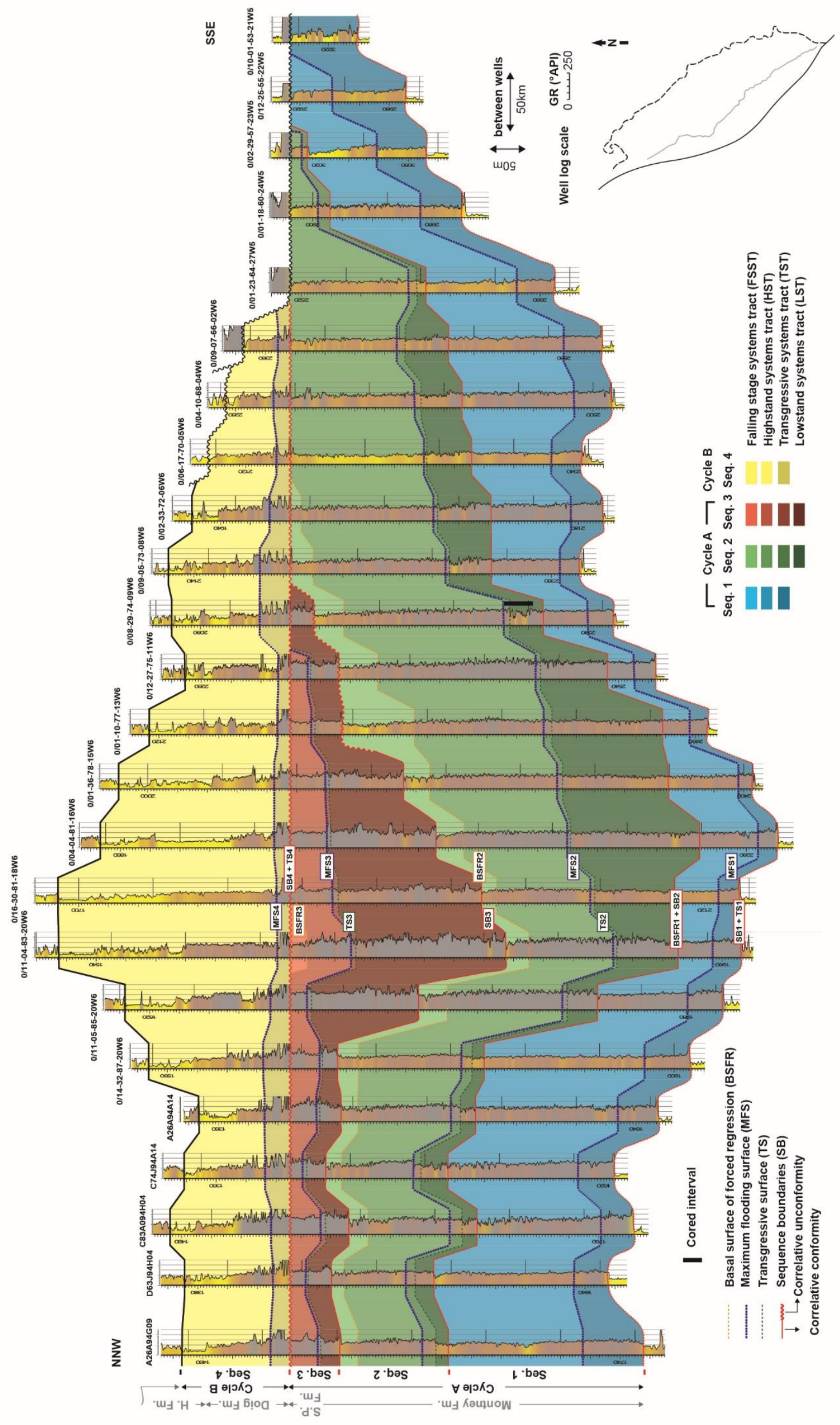

Figure 6 


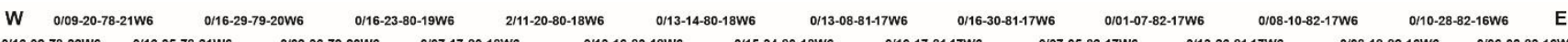

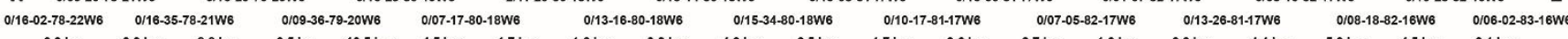

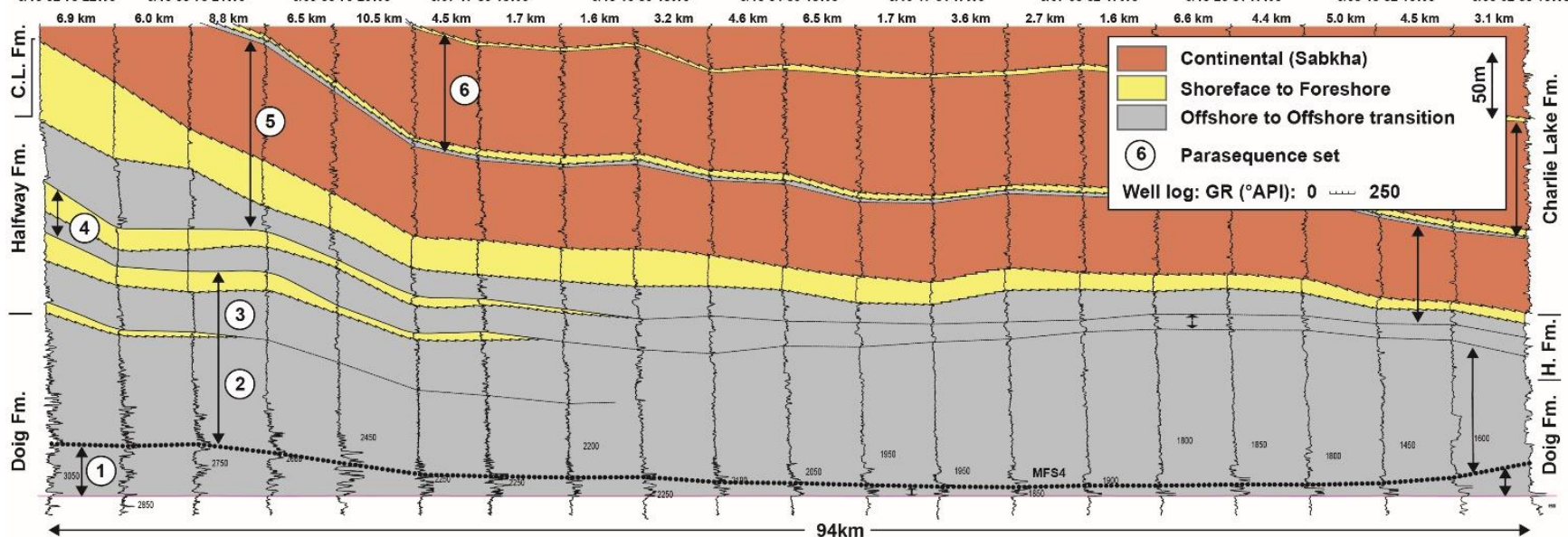

Figure 7 


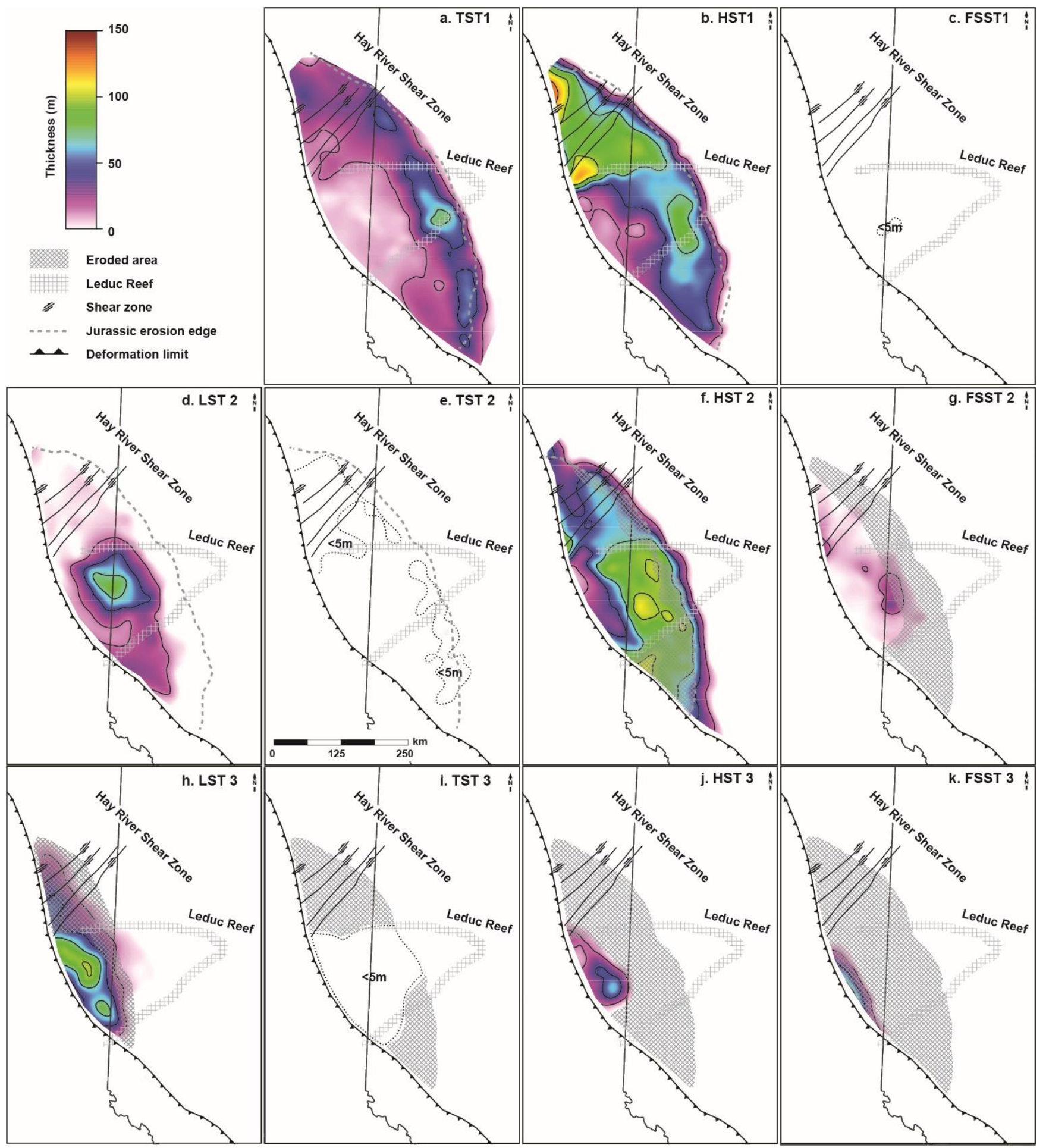

Figure 8 


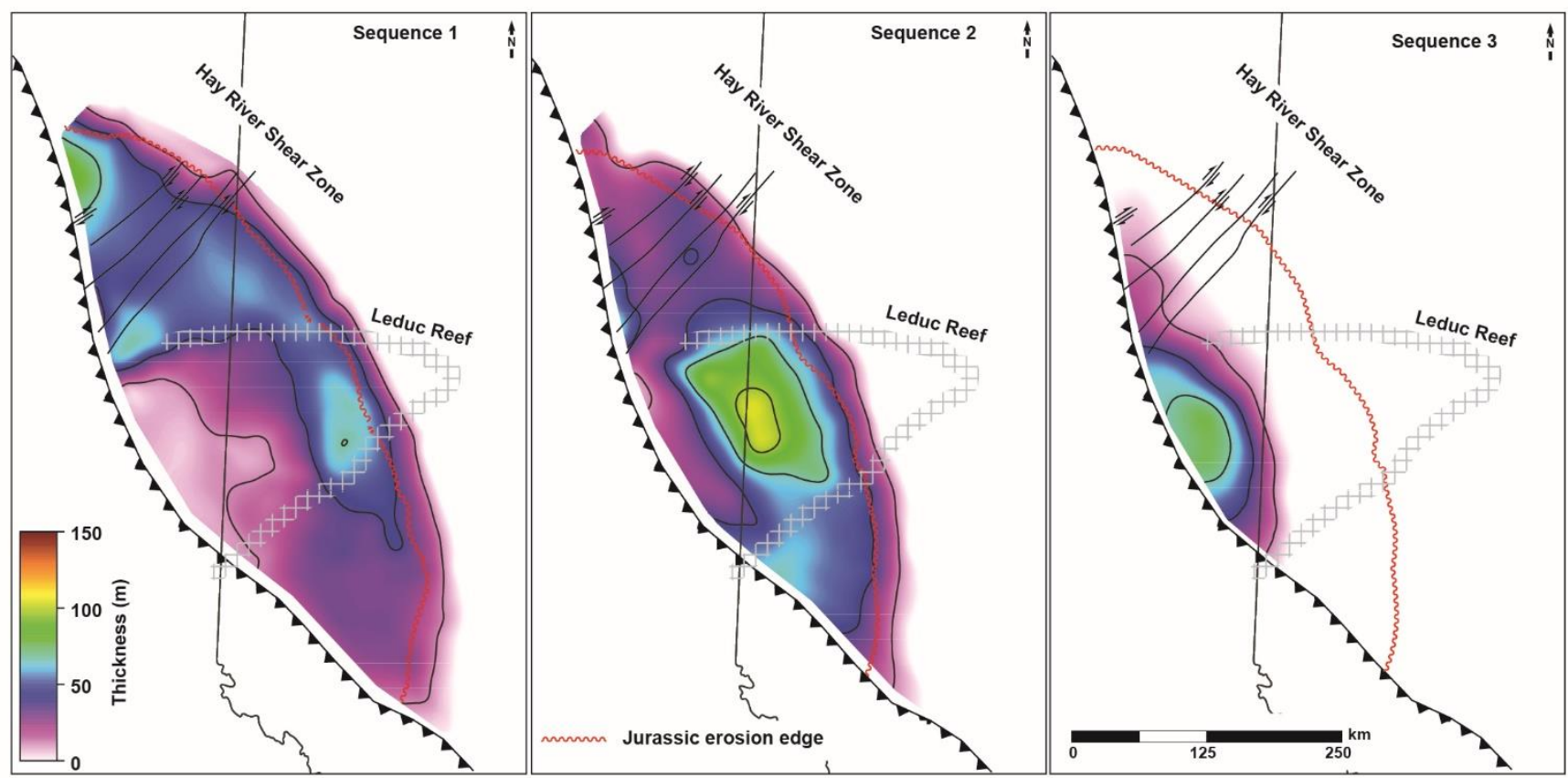

B. Sequence paleogeography

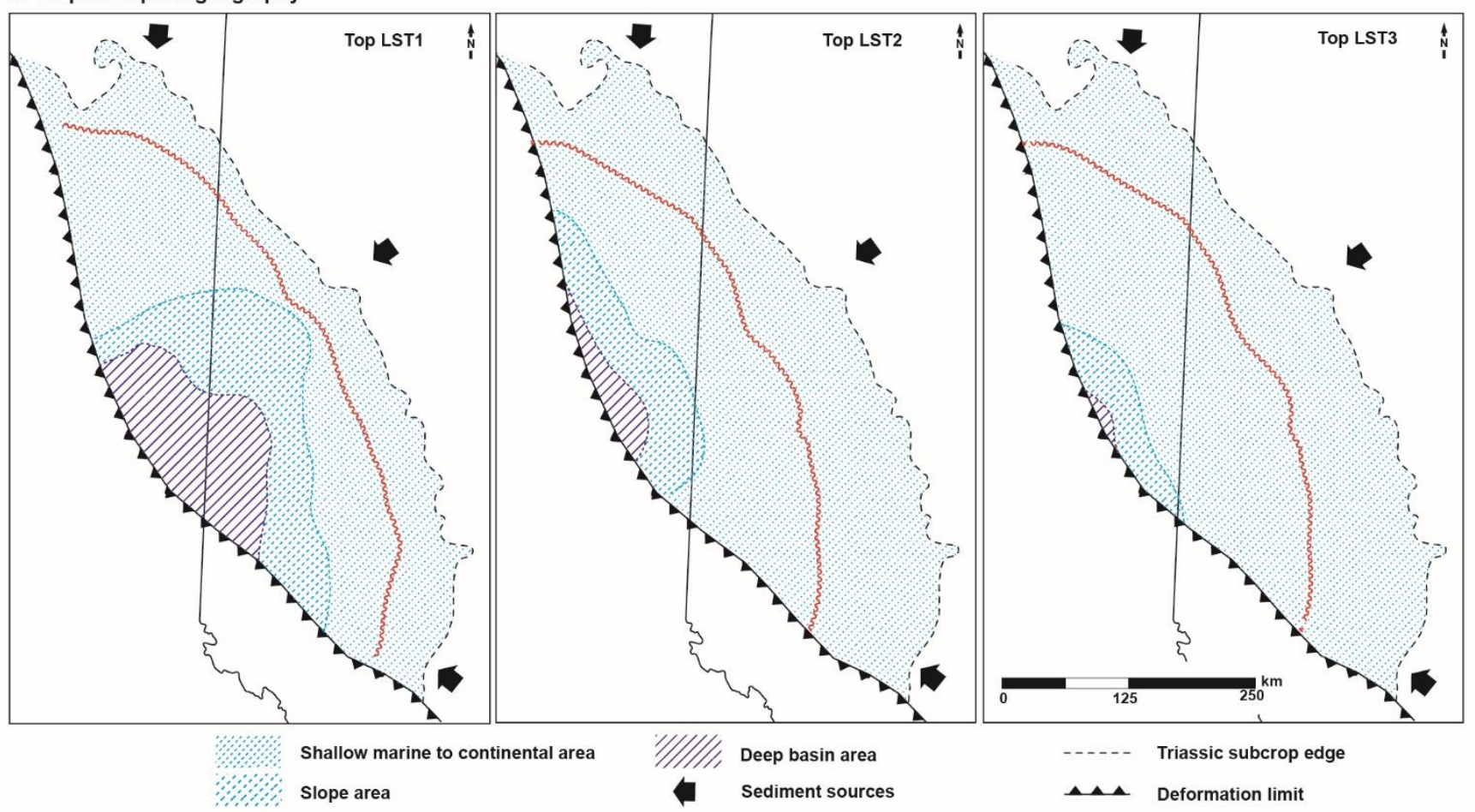

Figure 9 


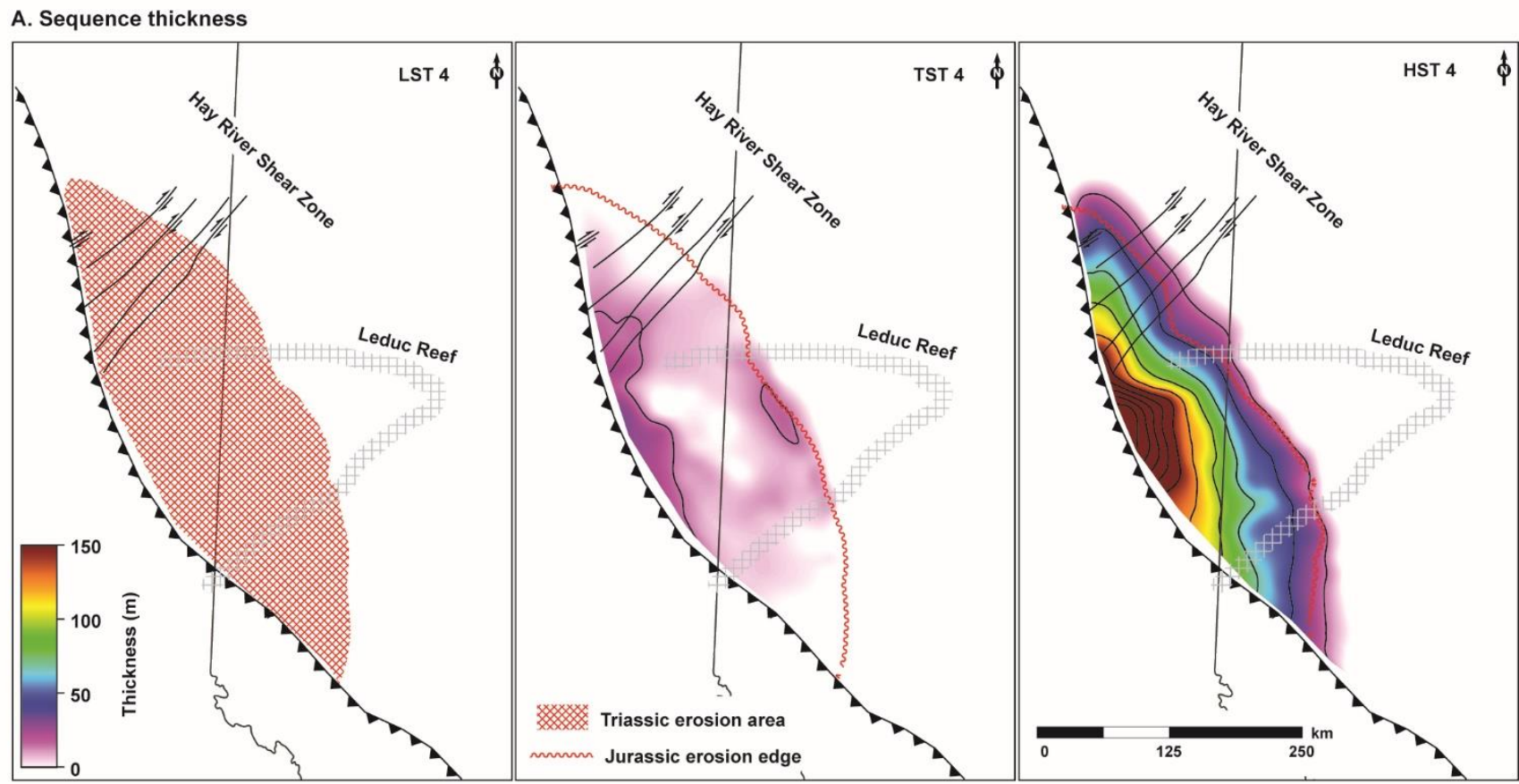

\section{B. Sequence paleogeography}

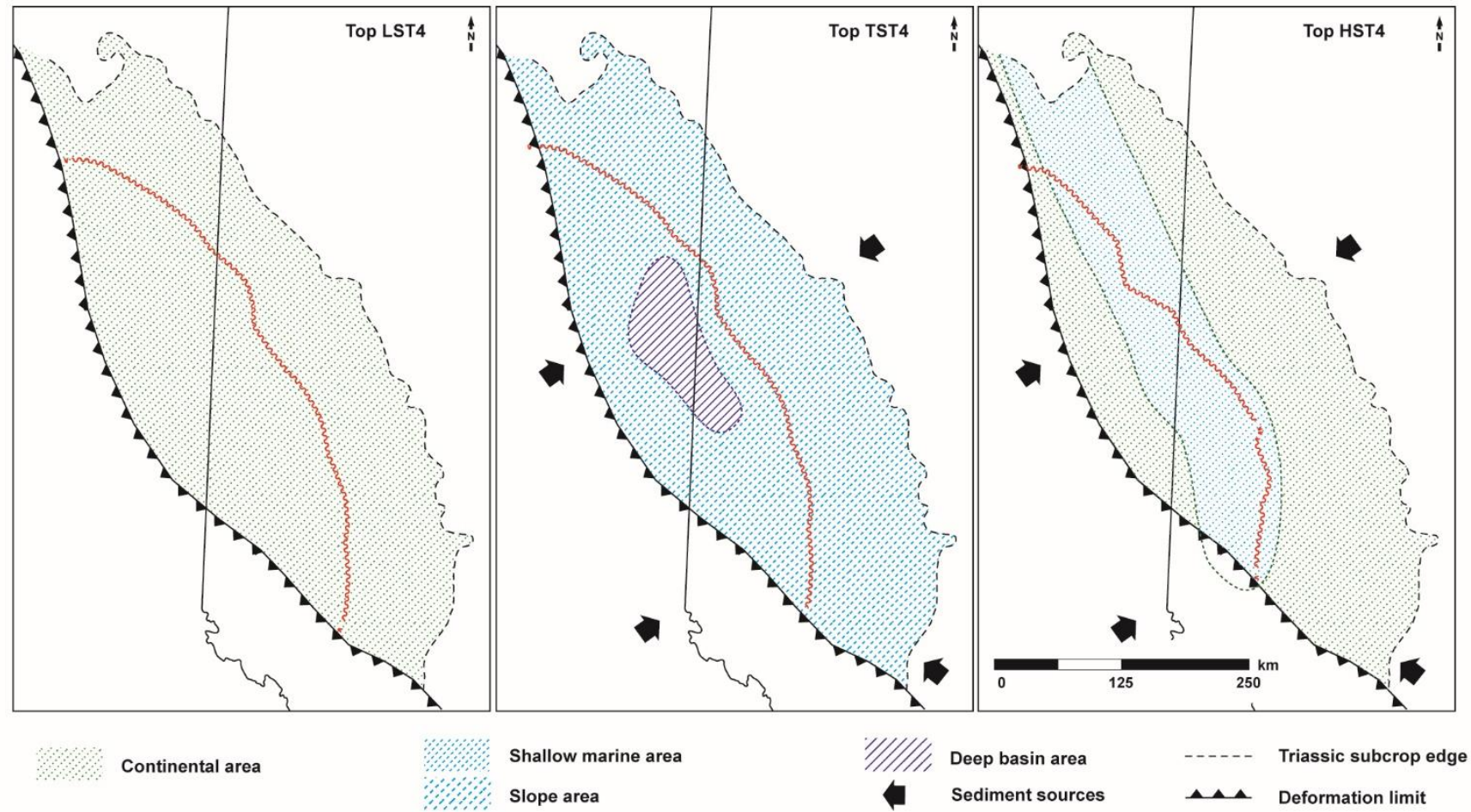

Figure 10 

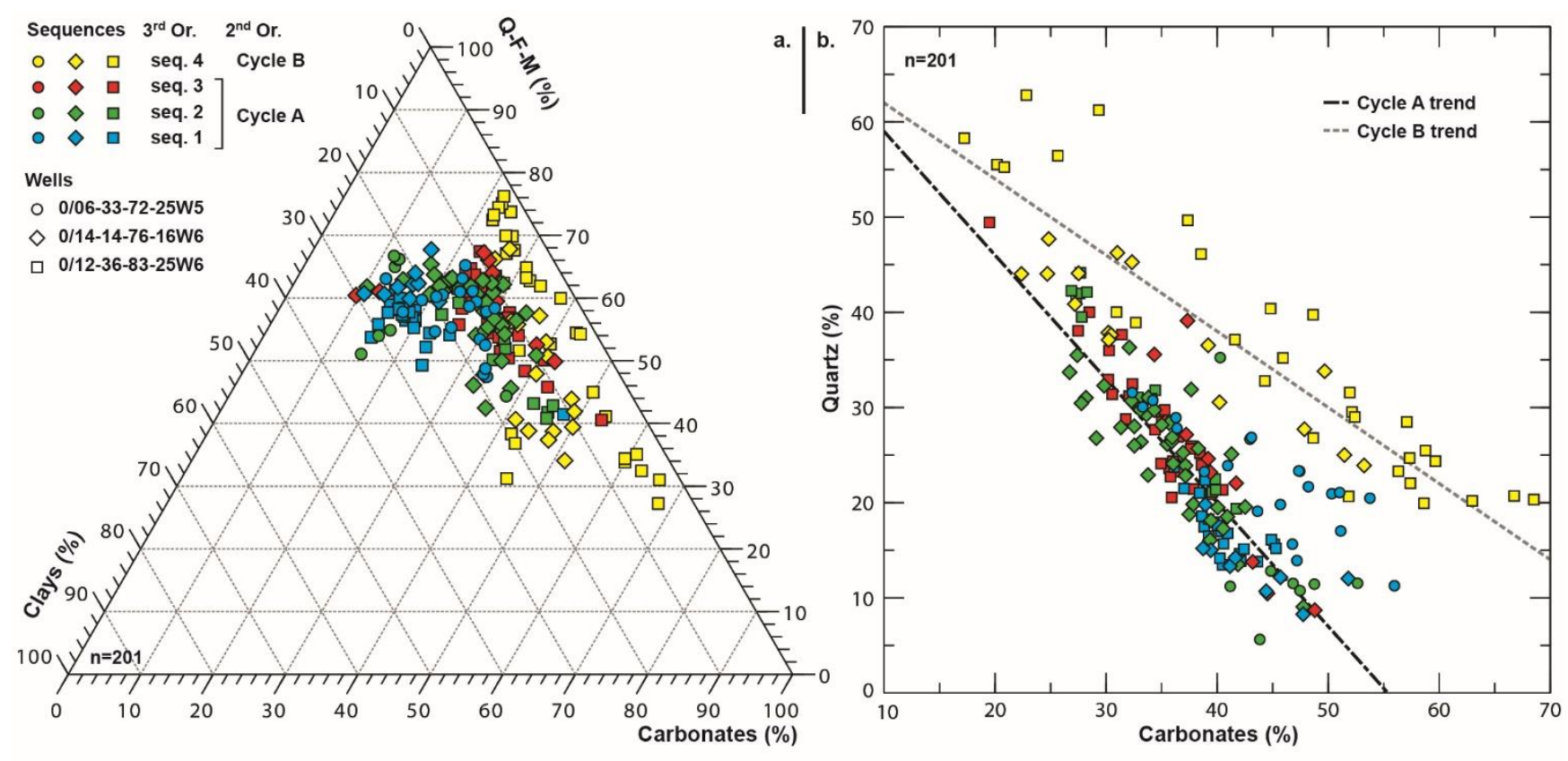

Figure 11 


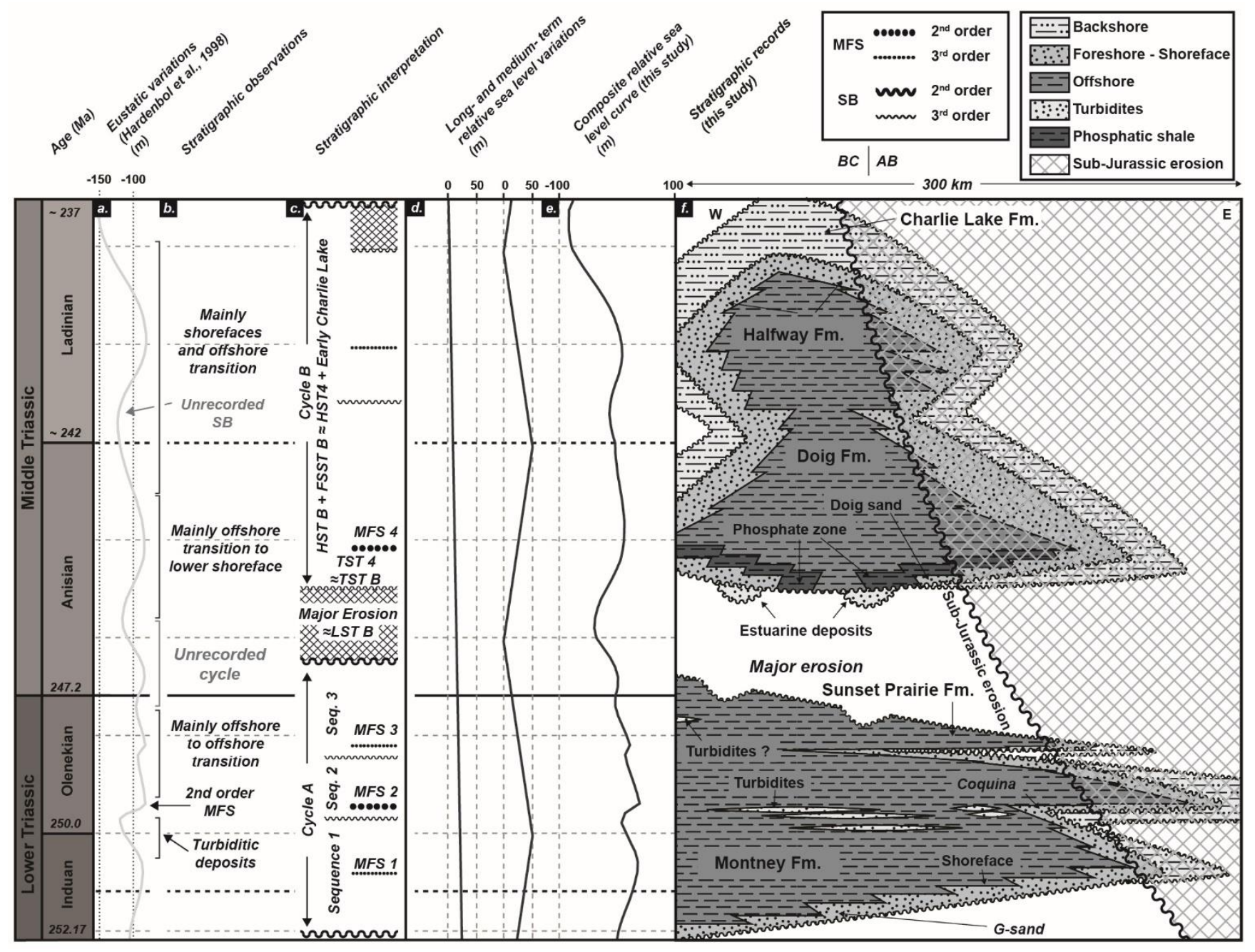

Figure 12 